Review

\title{
X-ray Photoelectron Spectroscopy in Mineral Processing Studies
}

\author{
Yuri Mikhlin (D) \\ Institute of Chemistry and Chemical Technology, Krasnoyarsk Science Center of the Siberian Branch of the \\ Russian Academy of Sciences, Akademgorodok 50/24, 660036 Krasnoyarsk, Russia; yumikh@icct.ru
}

Received: 22 June 2020; Accepted: 23 July 2020; Published: 26 July 2020

Featured Application: This article reviews the applications of X-ray photoelectron spectroscopy in beneficiation and hydrometallurgy of sulfide minerals and ores of base and precious metals aiming at understanding the surface phenomena and reaction mechanisms required to improve the flotation and leaching performance.

\begin{abstract}
Surface phenomena play the crucial role in the behavior of sulfide minerals in mineral processing of base and precious metal ores, including flotation, leaching, and environmental concerns. X-ray photoelectron spectroscopy (XPS) is the main experimental technique for surface characterization at present. However, there exist a number of problems related with complex composition of natural mineral systems, and instability of surface species and mineral/aqueous phase interfaces in the spectrometer vacuum. This overview describes contemporary XPS methods in terms of categorization and quantitative analysis of oxidation products, adsorbates and non-stoichiometric layers of sulfide phases, depth and lateral spatial resolution for minerals and ores under conditions related to mineral processing and hydrometallurgy. Specific practices allowing to preserve volatile species, e.g., elemental sulfur, polysulfide anions and flotation collectors, as well as solid/liquid interfaces are surveyed; in particular, the prospects of ambient pressure XPS and cryo-XPS of fast-frozen wet mineral pastes are discussed. It is also emphasized that further insights into the surface characteristics of individual minerals in technological slurries need new protocols of sample preparation in conjunction with high spatial resolution photoelectron spectroscopy that is still unavailable or unutilized in practice.
\end{abstract}

Keywords: X-ray photoelectron spectroscopy; sulfide minerals; surface; oxidation; flotation; leaching

\section{Introduction}

Surface composition and structure are critically important for minerals behavior in a variety of natural processes and for mineral processing, particularly the recovery and separation of base metal sulfides by flotation, as well as their leaching in hydrometallurgy [1-4]. The products of surface oxidation and reactions of sulfides with flotation reagents and precipitates from the mineral slurries, which render hydrophobic/hydrophilic properties and phenomena that determine the ability of mineral particles to break the wetting water film and attach to a millimeter air bubble in the flotation process, are not well understood so far [5-10]. The characters of the reacting and modified surfaces as well as the near-surface regions affect the rates of dissolution and leaching, which are often very slow and considered as "passivation" of still debatable nature (for example, [11-14]).

Application of surface-sensitive techniques to this field, which is necessary in order to gain insights into the surface composition and chemistry, however, faces with a number of difficulties. The X-ray photoelectron spectroscopy (XPS, also known as electron spectroscopy for chemical analysis ESCA) is a powerful method for surface studies in materials science, catalysis, and other areas $[15,16]$, and is widely utilized for characterization of mineral surfaces and interfaces [10,17-24]. 
Alternative techniques such as Auger electron spectroscopy (AES) [25,26] and secondary ion mass-spectrometry (SIMS, TOF-SIMS) [27] are less informative regarding chemical bonding and also require an ultra-high vacuum environment (UHV). X-ray absorption spectroscopy (XANES/EXAFS), infrared spectroscopy (ATR-FTIR) and Raman spectroscopy are not generally surface-sensitive and unable to determine the total surface composition [18,19,22-24,28-32]. The photoelectron spectroscopy is based on the analysis of electrons emitted under X-ray irradiation from the core levels and the valence band in atoms of materials located in the near-surface region as a function of the binding energy (BE) [15]. The binding energies of the photoelectrons are derived from the known energy of the incident $\mathrm{X}$-ray photons ( $\mathrm{h} v$ ) and the measured electron kinetic energy (KE) as $\mathrm{BE}=\mathrm{h} v-\mathrm{KE}-\varphi$, where $\varphi$ is the work function of the photoelectron analyzer. The intensities and chemical shifts of the photoelectrons provide information about the surface composition and the chemical state of the elements. The probing depth can be estimated by the electron inelastic mean free path (IMFP) in solid that depends on the kinetic energy of the electron (and on the solid constituents) and is usually in the range of $1-5 \mathrm{~nm}$ for laboratory instruments with $\mathrm{Mg} \mathrm{K} \alpha(1253.6 \mathrm{eV})$ or $\mathrm{Al} \mathrm{K} \alpha(1486.6 \mathrm{eV})$ irradiation of the X-ray tube anodes, but can be substantially varied with the excitation photon energy, particularly, using synchrotron radiation facilities (SR-XPS) [10,15,16,24]. XPS measurements traditionally have required ultra-high vacuum (UHV) because: (i) the detector needs to operate under this pressure regime, (ii) the surface contamination should be minimized, and (iii) potential inelastic collisions of the ejected electrons in their way to the detector should be also minimized since if the photoelectrons lose energy, then information is also lost. This is the main problem of XPS in studies of the solid/gas and solid/liquid interface [33]. Another problem is very complex multi-phase and multi-component composition of aqueous dispersions of minerals with practical solid-to-liquid weight ratios from 1:1 to 1:5 [1-4].

In this review, we consider applications of XPS with regard to the most common metal sulfide minerals (galena PbS, sphalerite $\mathrm{ZnS}$, chalcopyrite $\mathrm{CuFeS}_{2}$, pyrrhotite $\mathrm{Fe}_{1-\mathrm{x}} \mathrm{S}$, pyrite $\mathrm{FeS}_{2}$, and some others), and their ores. The metal sulfides are the main source of base metals in nature, and are also of vivid interest for materials science. In comparison with the previous reviews of mineral surface studies [5-10,17-24], this contribution is focused on methodological aspects, modern trends and developments of XPS along with the limitations concerning elusive (volatile, unstable or buried) entities on sulfide minerals, and the techniques aimed at (quasi) in situ approach. Only some important papers from the XPS application history are overviewed here, and only selected results are discussed in detail as examples. The studies, which utilized XPS for examination of concrete mineral systems, as well as those on the chemical bonding in metal sulfides, mineralogical and geochemical issues, are largely left aside, and we refer the readers to the articles summarizing the findings on specific minerals and the bibliography therein [13,34-39].

\section{Speciation of Surface Products}

\subsection{Oxidized Surfaces of Metal Sulfides}

\subsubsection{Detection of Elemental Sulfur, Sulfate, and Oxysulfur Species}

Some important possibilities and complications of the XPS method have been highlighted in early studies performed at single minerals and synthetic metal sulfides. Manocha and Park [40] have undertaken one of the first XPS (ESCA) research on sulfide minerals to resolve contradictions about the products of $\mathrm{PbS}$ oxidation under various conditions found with common surface-insensitive techniques. It has been stated that lead sulfate is the major product of oxidation of $\mathrm{PbS}$ in air and aqueous environments, while elemental sulfur formed in the early reaction stages; another product is $\mathrm{PbO}$ followed by slow adsorption of hydroxide ions. Brion [41] has compared oxidation of main sulfide minerals in air and water and found sulfate and, in the case of Fe-bearing minerals, $\mathrm{Fe}$ (III) (hydr)oxides as the main surface products, with the rate of sulfation decreasing in the order $\mathrm{FeS}_{2}>\mathrm{CuFeS}_{2} \geq \mathrm{PbS}>\mathrm{ZnS}$, which looks debatable at present [10,35-39]. Evans and Raftery [42] have studied the initial surface 
oxidation of natural PbS crystals using angle-resolved photoelectron spectroscopy and pointed out that elemental sulfur tends to be lost in vacuum but some $S$ remained trapped under an oxidized layer. Luttrell and Yoon [43] have characterized chalcopyrite surfaces with a focus on the formation of elemental sulfur as a hydrophobizing agent under collectorless flotation conditions and suggested that the presence of polysulfide species could explain some contradictions between XPS and other methods.

Buckley and Woods [44-55] have performed a series of studies on the sulfide minerals reacted in air, flotation- and leaching-related aqueous media, and highlighted the existence of metal-deficient surfaces involving S-S bonding and the necessity to cool the samples down to liquid nitrogen (LN) temperatures in order to preserve volatile surface species. In particular, galena crystals oxidized in air or reacted with aqueous solutions and then dried with Ar flushing were cooled to about $180 \mathrm{~K}$ during evacuation and measured at LN temperatures [44]. Elemental sulfur formed due to oxidation of galena was demonstrated to remain at the frozen samples and to volatilize after warming up to room temperature in UHV. Furthermore, Laajalehto et al. [56] have shown that the sulfur can be kept on such cooled samples under intense synchrotron radiation.

\subsubsection{Metal-Deficient and Polysulfide Surfaces}

Buckley and Woods have also found [44-55] that oxidation of metal sulfides in atmosphere and aqueous media generally produces surfaces depleted in metal and so enriched in sulfur. The initial oxidation typically yields metal oxides and hydroxide with no oxidized sulfur species, suggesting the formation of "defective metal-deficient" sulfide surfaces. If the deficit of a metal becomes large, the S 2 p lines at higher binding energies arise, suggesting S-S bonding and "polysulfide" surfaces. These effects were found for a majority of sulfide minerals, including pyrite $[49,57,58]$ containing disulfide groups, which is the most resistive to oxidation so quantities of polysulfide are the smallest in comparison with other sulfides. The surface non-stoichiometries induced by the preferential release of metals from the lattice are important phenomena for mineral processing and adjacent areas because they affect hydrophobic/hydrophilic characteristics (polysulfide surface is commonly assumed to be hydrophobic $[10,17,18])$, reactivity and mechanisms of various reactions of metal sulfide phases, including passivation in the hydrometallurgical leaching. Even small, within the error of XPS analysis, stoichiometry deviations can dramatically change the semiconducting properties of metal chalcogenides, surface charge distribution, etc., as shown, for example, for galena [59-61].

The studies [62-68] performed with the aim to understand the surface S-S species have elucidated that the end atoms in polysulfide anions bear negative charges similar to that in disulfide groups with the $\mathrm{S} 2 \mathrm{p}_{3 / 2} \mathrm{BE}$ about $162.5 \mathrm{eV}$. A small charge may be localized at $\mathrm{S}$ atoms nearest to the terminal ones [66], while intermediate atoms are close to elemental sulfur with almost no charge and $\mathrm{BE}$ between 163 and $164 \mathrm{eV}$. The occurrence of polysulfides on reacted sulfide mineral surfaces was confirmed with Raman spectroscopy (not quite surely, though) $[57,69,70]$ and TOF-SIMS [71] and other techniques. Polysulfides are thought to be stable in the spectrometer vacuum, in contrast to elemental sulfur [44-58,63-68].

At the same time, Klauber et al. [72-74] have reported that the intensity of $S 2 p$ bands attributable to polysulfides at chalcopyrite decreased with time as the sample was kept in UHV at room temperature. The "polysulfide" lines have been suggested to belong to elemental sulfur adsorbed at metal-deficient surface and the sulfur gradually evaporated at room temperature, whereas polysulfides do not actually exist [72]. This, however, contradicts numerous findings, including the S-S species detected in much deeper sulfide layers and transformations of S-S bonding observed in (electro)chemical reactions [75-88]. The inconsistency seems to be resolved by using hard XPS depth profiling $[89,90]$ which elucidated that the metal-depleted surfaces are composed of several layers with only the outer one containing polysulfide anions. Nasluzov et al. [68] found with DFT $+U$ simulation and cryo-XPS of fast-frozen chalcopyrite (Figure 1) that the polysulfides as intermediates to elemental sulfur are surprisingly stable and hinder the release of elemental sulfur (see Section 3.3 for details). 

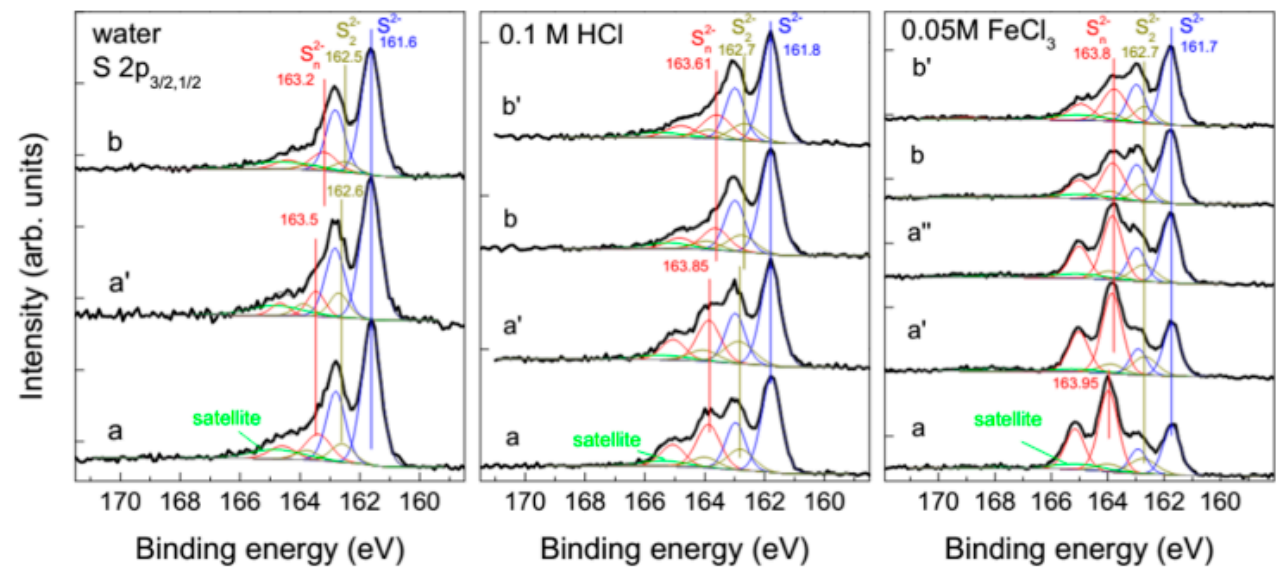

Figure 1. X-ray photoelectron S 2 p spectra of particulate chalcopyrite conditioned in water, $0.1 \mathrm{M} \mathrm{HCl}$, and $0.05 \mathrm{M} \mathrm{FeCl} 3+0.01 \mathrm{M} \mathrm{HCl}$, centrifuged, fast-frozen and measured at $-160{ }^{\circ} \mathrm{C}\left(\mathrm{a}, \mathrm{a}^{\prime}\right),-40{ }^{\circ} \mathrm{C}\left(\mathrm{a}^{\prime \prime}\right)$, and $+25^{\circ} \mathrm{C}\left(\mathrm{b}, \mathrm{b}^{\prime}\right)$. The spectra $\mathrm{a}^{\prime}$ and $\mathrm{b}^{\prime}$ measured employing an electron flood gun. Reproduced from [67] with permission from ACS.

\subsection{Flotation Reagents}

Oxidation of sulfide minerals notably affects their hydrophobicity and floatability but flotation reagents play the main role in their recovery and separation $[2,5,8-10,18,22,91-94]$. Sulfhydryl collectors, particularly alkyl xanthates are the most common reagents $[2,5,8,10]$, so we restrict this overview to xanthates as a representative example. The main efforts of researchers have been concentrated on elucidating the chemical state of adsorbates [10,18,22,23,29-31,95-103]. It has been established [92-103] that alkyl xanthates of alkali metals can be attached to sulfide mineral surfaces as chemisorbed xanthate radicals, metal xanthates, or dialkyl dixanthogens, depending on the nature of the mineral, collector concentration, electrochemical potential and mineral pre-oxidation, and other conditions. Nevertheless, a large amount of uncertainty still remains because the analytical techniques have insufficient surface sensitivity and the lack of in situ measurements, particularly in technological media.

In the case of XPS, it is necessary to discern weak signals of $S$ atoms in xanthate-derived surface species having the $S 2 p_{3 / 2}$ binding energies of $162-162.5 \mathrm{eV}$ for chemisorbed xanthate and metal xanthates and 163.5-164.2 eV for dixanthogens [92,95,98-103] from the spectra of di- and polysulfides in underlying metal sulfide phase; the spectra of $O$ and $C$ are usually less informative due to surface oxygen and carbon contaminations. To overcome this obstacle, higher xanthate concentrations are often utilized, which may lead to unpractical results. The samples evacuated at room temperature, typically rinsed to remove solution components, could loss interfacial volatile and soluble species of interest. When sulfide minerals reacted with xanthate solutions were dried and cooled to LN temperature [98-100], or prepared as fast-frozen wet particulate paste [102,103], XPS recognizes dialkyl dixanthogens, which otherwise evaporate in UHV. The cryo-XPS data (see Figure 2 for an example) show that dixanthogens are the major adsorbate at pyrite, dixanthogen and cuprous xanthate formed in the next stage on chalcopyrite and $\mathrm{Cu}$-activated sphalerite and pyrite, while predominant chemisorbed xanthate is present on galena. In general, one can conclude that the quantities of dixanthogens were underestimated whereas those of metal xanthates overestimated previously. This may be explained in part by the fact that metal xanthates tend to form nanoparticles with lower visible surface [104,105], whereas dixanthogen continuously (but not completely) covers the mineral surface [106].

XPS has been extensively used for characterization of mineral surfaces modified with flotation activators, depressors and other reagents. Noteworthy, organic reagents, which are physically adsorbed on sulfides and volatile in the UHV, are not well suitable for XPS examination. Especially large attention has been paid to the interaction of $\mathrm{Cu}^{2+}$ with sulfide minerals, mainly sphalerite and pyrite, and following interaction with flotation collectors, including experimental, theoretical, and review works [103,107-119]. The XPS and SR-XPS studies, including those performed at low temperatures, 
have established that copper deposits at sphalerite mainly forms a non-stoichiometric $\mathrm{Cu}^{+}-\mathrm{Zn}$ sulfide but not a single copper sulfide phase, with polysulfide anions formed due to oxidation of $\mathrm{ZnS}$ by cupric ions and dissolution of $\mathrm{Zn}$; some $\mathrm{Cu}^{2+}$ hydroxide colloids can precipitate on the surface under higher $\mathrm{pH}$ conditions [116]. Notwithstanding, there are still perceptual gaps in understanding the reaction mechanisms and surface products, and their relation to the flotation practice, which can be explained by a wide variety of factors influencing these processes, e.g., heterogeneity of minerals. Thus, the experimental techniques with a better spatial resolution and spectral sensitivity are required under conditions typical of a plant environment [116].
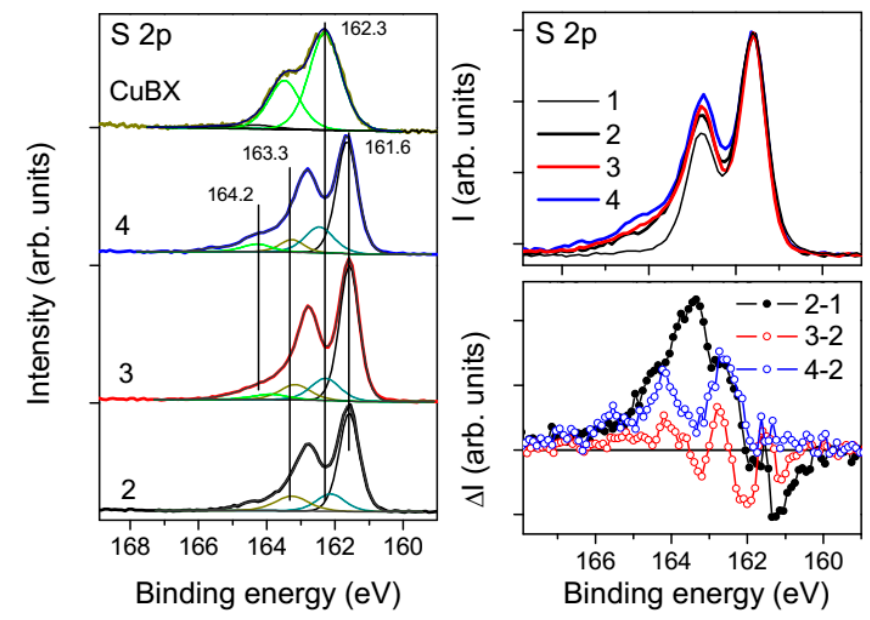

Figure 2. Cryo-XPS S 2p spectra from fast-frozen sphalerite (1) ground, (2) reacted with $0.1 \mathrm{mM} \mathrm{CuSO}_{4}$, the activated mineral treated with (3) $0.1 \mathrm{mM} \mathrm{KBX}$ and (4) $10 \mathrm{mM} \mathrm{KBX.} \mathrm{Right} \mathrm{panels} \mathrm{show} \mathrm{the} \mathrm{bands,}$ normalized by the height and shifted to align the peak position, and the differences between the spectra. For clarity, only S 2 $p_{3 / 2}$ components are shown in the S 2p spectra fitting. Reproduced from [102] with permission from Elsevier.

\subsection{Quantitative Analysis of Mineral Surfaces}

XPS is crucial for the quantitative surface composition analysis, despite both inherent limitations, such as accuracy, different surface sensitivity for various spectral lines, effect of surface roughness, and some others $[15,16]$, and additional difficulties arising from real mineral systems $[10,17-19,23,24]$. Possible loss of surface substances could occur due to washing or other pretreatment before the sample transfer to a spectrometer and in vacuum. In XPS, the concentrations of atomic species can be evaluated and attributed to visible surface area, which depend on morphology of the products, e.g., whether those form uniform coatings on the mineral or entities of notable height. In particular, atomic force spectroscopy showed [18,61,120-123] that the products, mainly elemental sulfur, form protrusions up to hundred nanometers in height so their quantities could be underestimated in XPS, even if sulfur sublimation is suppressed through freezing the sample. Another interesting example is so-called invisible gold in metal sulfides that was detected by XPS when presented as Au nanoparticles. The apparent $\mathrm{Au}$ concentration can become lower than the detection limit if Au forms micrometer-scale particles despite of its higher total content [124]. Furthermore, ultrafine particles of gangue minerals and other components of real slurries could cover sulfide minerals and complicate the surface analysis [17].

\section{Spatial Resolution of Photoelectron Spectroscopy}

The previous studies and findings of photoelectron spectroscopy, along with other techniques and mineral processing practice $[10,17,117]$, have exposed the issues needed to be answered with XPS. For instance, it is known that about $50 \%$ monolayer xanthate coverage of a sulfide surface is enough for flotation recovery of the mineral $[5,10]$, so the question arises of how the collectors, oxidation products, and other surface species are spatially distributed and how this influences the hydrophobicity 
and flotation. It is also difficult to distinguish mono- and multilayer coatings of flotation reagents [125]. Knowing the distribution of reaction products is necessary in order to understand the origin of retarded reaction kinetics and "passivation" of metal sulfide oxidation and leaching. Therefore, researchers need XPS techniques having a high spatial resolution, both lateral and in-depth, which also cause minimize alterations of the mineral/aqueous interfaces upon measurements.

\subsection{Ion Sputtering and Depth Profiling}

Information about depth-resolved concentrations of elements and morphology of products, thicknesses of surface layers of adsorbates, etc., can be obtained in XPS by several methods $[15,16]$. First, atoms from outer layers can be removed by sputtering with heavy ions, usually $\mathrm{Ar}^{+}$ions, exposing deeper structures. The $\mathrm{Ar}^{+}$bombardment causes substantial disordering of crystal and electronic structures, reduction of some elements, and so on, so the information on the chemical state of atoms will be lost; moreover, elemental composition can change under the ion beam, too. For example, ion bombardment of pyrite results in preferential removal of $S$ atoms, producing disordered layer with high-spin $\mathrm{Fe}^{2+} / \mathrm{Fe}^{3+}$ cations and sulfide anions instead of singlet ferrous iron and disulfide groups [126,127]. Nevertheless, the $\mathrm{Ar}^{+}$bombardment is often employed for depth-profiling down to about $100 \mathrm{~nm}$, although for rough and inhomogeneous surfaces of real, oxidized sulfide minerals it provides semi-quantitative concentration distributions at best. It is more convenient in such situations to use the ion bombardment together with Auger electron spectroscopy $[25,26]$ because of the smaller size of an electron beam; see for example, studies of oxidized and leached pyrrhotite [76-79]. In addition to profiling, mild $\mathrm{Ar}^{+}$sputtering is used to clean surfaces from casual contaminations.

\subsection{Surface-Sensitive Techniques}

Non-destructive XPS with varying analysis depth is based on changing the thickness of the layer from which photoelectrons escape without loss of energy $[15,16,128]$. The thickness can be decreased by several times if the electron take-off angle is reduced from $90^{\circ}$ to $15-20^{\circ}$ although this provides a limited probing depth range and is not very suitable for rough surfaces and especially for particulate materials. This option realized in many XPS instruments can be easily used to enhance surface sensitivity and to distinguish, for example, more or less uniform surface coating and bulk particles. Another easy way to estimate the depth distribution is by comparing the core level spectra with different binding energies (and the kinetic energy of emitted electrons), for example $\mathrm{Cu} 2 \mathrm{p}_{3 / 2}$ (BE of about $932 \mathrm{eV}$ ) and $\mathrm{Cu} 3 \mathrm{p}$ $(60 \mathrm{eV}), \mathrm{Fe} 2 \mathrm{p}_{3 / 2}$ and $3 \mathrm{p}$ (709 and $54 \mathrm{eV}$, respectively), as the electron IMFP at high energies is roughly proportional to the square root of the kinetic energy [15].

Alternatively, the kinetic energies of photoelectrons can be changed by varying the energy of synchrotron excitation photons in the range from about $100 \mathrm{eV}$ to tens of $\mathrm{keV}[15,128,129]$. The soft SR-XPS has been applied in order to increase the surface sensitivity in a number of studies on the structure and initial reaction stages on fractured sulfide surfaces, adsorption of flotation collectors [130-151] and activators [152]. For example, S 2p spectra allowed to distinguish outmost S atoms having lower coordination with metals and S-S bonding arising at reconstructed or/and oxidized surfaces [130-137]. The high-flux synchrotron radiation could damage the surface layers due to heating and photodecomposition effects but the distortions can be significantly reduced at the samples cooled to LN temperatures. Thus far, the synchrotron studies [129-152] have been mostly fulfilled at compact mineral specimens with moderately modified surfaces.

\subsection{Hard X-ray Photoelectron Spectroscopy}

The probing depth can be increased with increasing energies of excitation photons far beyond those applied in the common laboratory spectrometers. The high-energy photoemission spectroscopy, or hard XPS (HAXPES) $[128,153]$, most often utilizes the photon energies tunable from $2 \mathrm{keV}$ to $10 \mathrm{keV}$ at many synchrotron facilities and characterizes the layers extending up to 20-30 nm in depth. Commercial instruments employing hard X-ray sources, particularly with $\mathrm{Cr}(5.417 \mathrm{keV})$ and 
liquid Ga $(9.243 \mathrm{keV})$ anodes $[154,155]$, are developed now too. The HAXPES is an effective tool for destruction-free examination of multilayered structures, and surfaces and interfaces buried under reaction products, which provides information about both the concentration as a function of the excitation photon energy (depth profiles) and the depth-resolved chemical form of elements [130]. Certain shortcomings of the compositional analysis arise for samples with complex morphology of near-surface regions due to multiple elastic scattering, and because the photoionization cross-sections of core shells essentially depend on the excitation energy [128,153-155]. HAXPES looks as a very promising technique for characterization of real heavily reacted and contaminated surfaces in mineral processing but, to the best of our knowledge, only few HAXPES investigations of sulfide minerals were reported in the literature.

As an example, Mikhlin et al. [88,89] have applied HAXPES in conjunction with Fe K- and $\mathrm{S}$ K-XANES, and DFT $+U$ simulation to study polycrystalline chalcopyrite, pyrite, and pyrrhotite plates oxidized in air and aqueous $\mathrm{Fe}^{3+}$ solutions and developed Fe-depleted surfaces. It has been known that the metal deficiency induced by chemical reactions is not just a surface phenomenon and extends in depth up to hundreds nanometers as established with AES depth profiling [11,76-79], X-ray absorption and emission, and Mössbauer spectroscopy [80,81,87-89,148,149] but the nature of such heavily disordered structures has remained puzzling. HAXPES study discovered that the near-surfaces of mineral samples beneath some surface Fe oxides are stratified (Figure 3) and composed of an outer layer with high $S$ excess and polysulfide species, and then a metal-deficient zone with monoand disulfide anions, whose composition and thickness varied from a few $\mathrm{nm}$ to several tens of $\mathrm{nm}$, depending on the nature of mineral and reaction conditions. The underlayers up to a hundred $\mathrm{nm}$ in depth had no variations in the composition discernible in HAXPES but the changes in XANES suggested their high defectivity. The polysulfide centers located in the 1-2 outmost atomic layers were found to be energetically favorable under the oxidation conditions [68], so arresting the yield of elemental sulfur and promoting the formation of thick metal-depleted layers. These findings shed new light on the origin of metal-deficient surfaces and highly debatable mineral "passivation" [11-14,71-74,156-160].
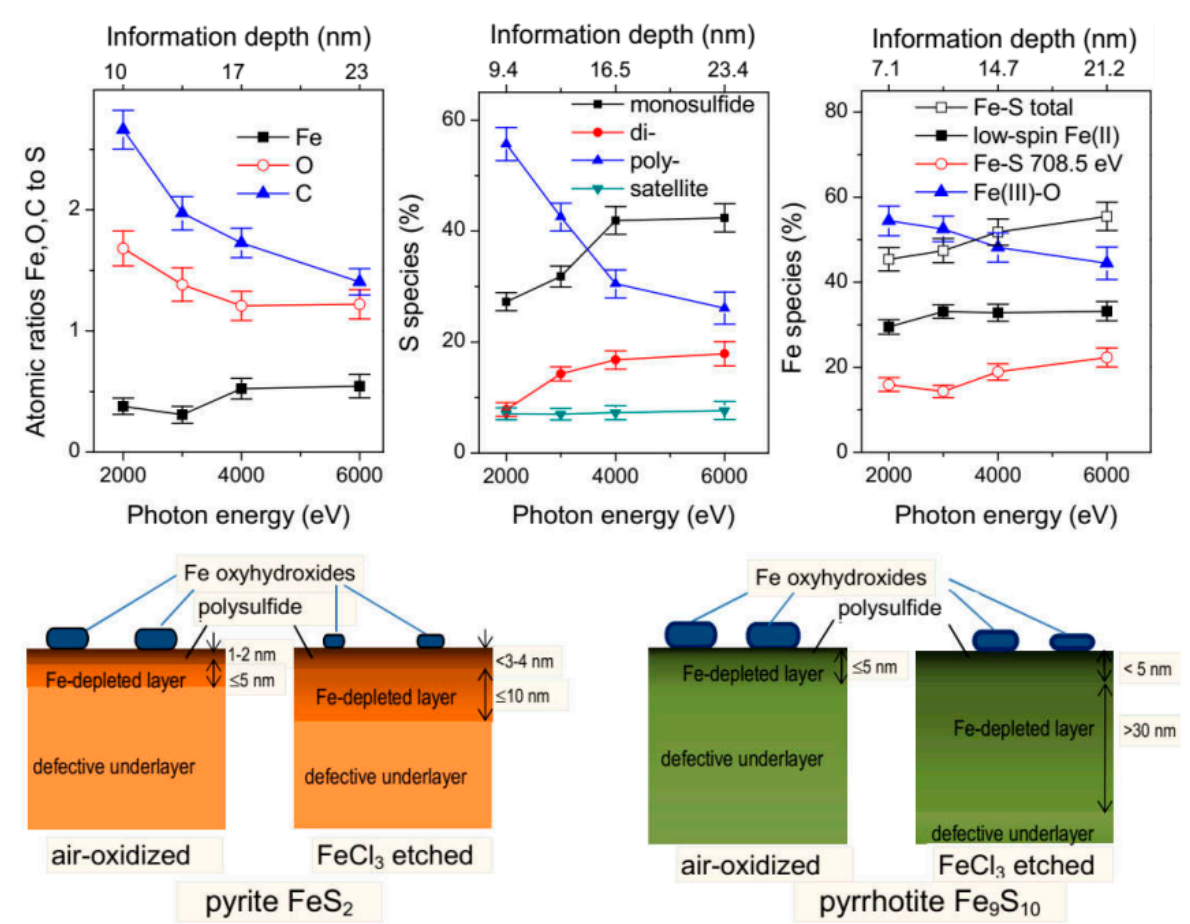

Figure 3. Atomic ratios and the results of fitting of the $S 2 p$ and Fe $2 p$ spectra as a function of excitation photon energy for pyrrhotite leached in acidic $0.5 \mathrm{M} \mathrm{FeCl}_{3}$ solution (top panels), and scheme illustrating layered structures of pyrite and pyrrhotite oxidized in air and the aqueous solution as derived from HAXPES and XANES. Adapted from [88] with permission from Elsevier. 


\subsection{Lateral Resolution of Photoelectron Spectroscopy}

Natural mineral systems are composed of plentiful phases with the particle size less than $100 \mu \mathrm{m}$ after the comminution [1,2], with the surfaces of single mineral particles being further inhomogeneous in terms of crystal faces exposed, roughness, impurity distributions, and so on. Conventional laboratory and synchrotron photoelectron instruments have resolutions on the order of a hundred $\mu \mathrm{m}$ and several $\mu \mathrm{m}$, respectively, at best. The high spatial resolution methods available at present are scanning X-ray photoelectron microscopy (SPEM, or XPEM) and photoemission electron microscopy (PEEM) [161-164]. In synchrotron SPEM, the photon beam focused to a spot of about $100 \mathrm{~nm}$ scans over the surface. Emitted photoelectrons are collected with an analyzer, providing local photoelectron spectra similar to conventional XPS or/and spectromicroscopy images with submicrometer resolution at selected excitation photon energies [161,162].

PEEM can be realized both as laboratory and synchrotron set-ups, with the latter often coupled with XANES technique $[163,164]$. PEEM provides surface chemical imaging by parallel acquisition of the photoelectrons emitted from the illuminated area. This allows reaching the lateral resolution as good as $10 \mathrm{~nm}$ at short measurement times, but information on chemical bonding is limited and should be extracted from a coupled technique, e.g. XANES. The methods have been applied to image distributions of various phases in natural mineral samples, including surface oxidation products across natural samples [164-167].

Interesting SPEM studies on reacted sulfide minerals have been performed by Gerson and co-workers [168-170]. The experiments were carried out using polished mineral slabs frozen after the treatment and measured using about $100 \mathrm{~nm}$ photon beam at LN temperatures at the ESCA Microscopy Beamline (ELETTRA). It has been found, for example, that $\mathrm{Fe}-\mathrm{O}$ bonds form prior to $\mathrm{Fe}-\mathrm{OH}$ bonds in initial stages of pyrite oxidation, $\mathrm{S}$ oxidation proceeds through interactions of $\mathrm{OH}$ radicals formed at the Fe sites, and sulfate forms, via thiosulfate/sulfite intermediates, in the patches, where adsorption of oxygen has been localized and Fe oxidation occurred. Chalcopyrite dissolution in $4 \mathrm{mM} \mathrm{Fe} \mathrm{F}^{3+}$ solution has been observed to be spatially heterogeneous at the submicrometer scale, producing diand polysulfide anions, elemental sulfur, sulfite, and sulfate (Figure 4). The surface heterogeneity has been concluded to indicate that the minerals are not passivated by these products.
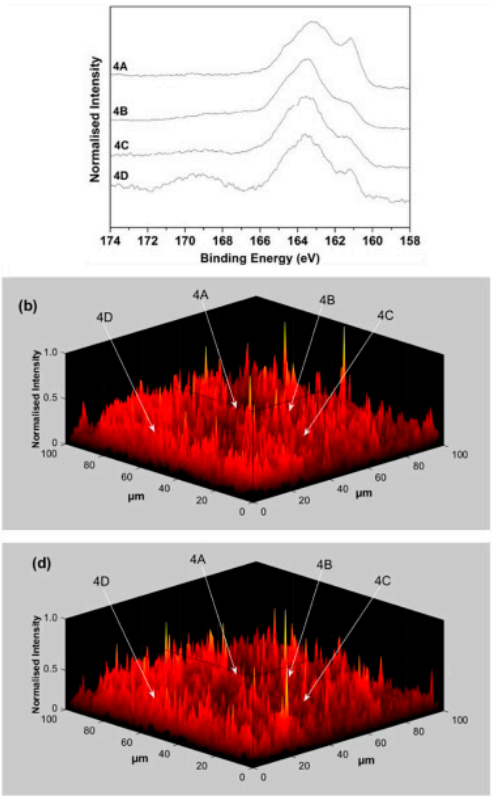
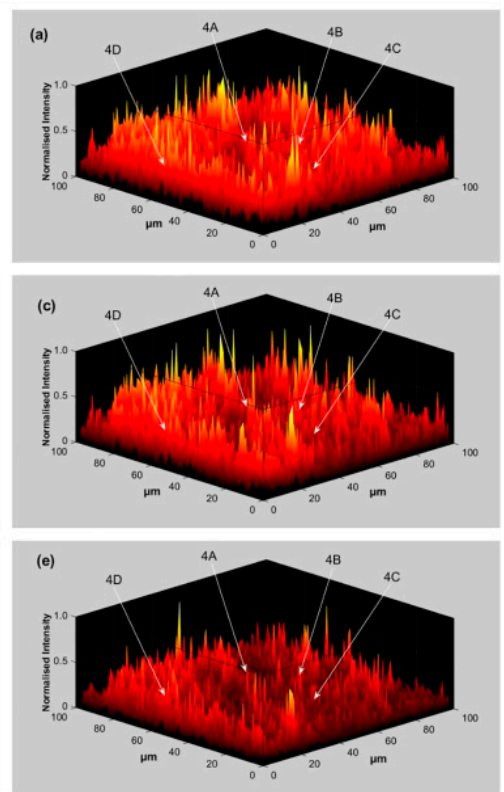

Figure 4. S 2p SPEM speciation maps (a) $\mathrm{S}^{2-}$, (b) $\mathrm{S}_{2}{ }^{2-}$, (c) $\mathrm{S}_{\mathrm{n}}{ }^{2-}$, (d) $\mathrm{S}^{0}$ and (e) $\mathrm{SO}_{3}{ }^{2-}$ collected from a region $(100 \times 100 \mu \mathrm{m})$ on the chalcopyrite surface partially dissolved with pyrite for 10 days containing spots 4A-4D (S 2p XPS spectra are shown in top left corner). Reproduced from [170] with permission from Elsevier. 
In general, PEEM and SPEM are not broadly used in mineral processing studies until now, in particular, because these methods require rather flat surfaces and well-conducting materials, in addition to access to SR facilities. XPS measurements spatially resolved in lateral dimension remain a challenge.

\section{Towards in Situ XPS}

\subsection{XPS Studies of Solid-Liquid Interfaces}

The application of in situ and operando XPS [33,171-179] is a vital problem in catalysis, materials science, electrochemical power sources, and other fields, and the minerals processing is not an exception. The behavior of minerals occurs at the interface between the aqueous phase and the (oxidized) minerals, which decays upon routine sample preparation and drying. XPS operation in the systems containing aqueous solutions is complicated by the high pressure of water vapor "forbidden" for the UHV installation and the attenuation of photoelectrons in gas and liquid phases. At present, there are two main approaches to this problem.

\subsubsection{Ambient Pressure XPS}

(Near) ambient pressure photoelectron spectroscopy ((N)AP-XPS) is a fast-developing technique allowing to characterize a sample at pressure up to about 100 mbar by using differentially pumped spectrometers [33,172-177]. Such equipment first advanced by Salmeron and co-workers [172] can work as backfilling system, in which the whole chamber is filled with gas, or the enhanced pressure is created in a reaction cell connected to the analyzer. Usually, the brilliant synchrotron radiation is utilized because of the photoelectron attenuation, but laboratory instruments equipped often with high-energy X-ray sources (e.g., $\mathrm{Cr}$ anode) are available now too $[173,179]$.

Several types of the cells have been proposed for samples containing a liquid $[33,173,174]$. The liquid microjet set-up, in which the liquid stream is injected with a high speed through the nozzle having a diameter of $20 \mu \mathrm{m}$ or smaller, is used for XPS studies of aqueous solutions, liquid-vapor and liquid-solid (nanoparticles) interfaces [179]. A "dip and pull" method has been utilized for a solid surface coated with a thin liquid layer up to $10 \mathrm{~nm}$ which has been fabricated by partially pulling up from a liquid reservoir placed in the analysis chamber; both the solution species and underlying substrate with adsorbates can be analyzed with XPS (HAXPES) [178]. In a technique based on SR or conventional X-ray tube sources, an environmental cell containing liquid, gas, or multiphase samples is sealed with a thin membrane (graphene, $\mathrm{Si}, \mathrm{Si}_{3} \mathrm{~N}_{4}$ ) as a window transmitting photoelectrons and separating it from the environment $[33,172,173,178,179]$.

To the best of our knowledge, NAP-XPS has not been used in mineral processing research to date; the main tasks here seem to be a creation of experiment methodology and proper cells.

\subsubsection{Cryogenic XPS}

A number of works considered above have employed low-temperature XPS for retaining surface substances unstable in vacuum at room temperature. In fact, the preparation, sometimes referred as "freeze-drying" [171], combined cooling and drying the sample in the entry lock chamber under controlled conditions in order to remove water but preserve volatile species of interest (sulfur, polysulfide, dixanthogens, and others). This procedure is usually preceded by washing to eliminate undesirable surface products and solution remnants since, otherwise, non-volatile solutes could uncontrollably precipitate at the interface.

Burger and co-workers [180] have proposed XPS as a tool for examination of aqueous solutions and demonstrated that their quick freezing to LN temperatures preserves the solution chemistry and prevents precipitation of solutes. More recently, Shchukarev [171,181-183] has developed the cryogenic XPS analysis of solid/aqueous phase interfaces using fast-frozen wet particulate materials, which allows retaining the volatile species together with a thin frozen film of adjacent aqueous phase. 
In a typical "fast-freezing" procedure [183], an aqueous dispersion is centrifuged and the supernatant is discarded; the wet paste is placed on a sample holder cooled to a liquid nitrogen temperature, and kept in the spectrometer lock chamber under a flow of dry $\mathrm{N}_{2}$ or Ar for 30-60 s prior to pumping to a vacuum of $10^{-6}$ to $10^{-7} \mathrm{mBar}$ in order to freeze the paste and evaporate (sublimate) excessive water (ice). The sample is transferred to the pre-cooled manipulator in the analysis chamber; its temperature is kept below $-150^{\circ} \mathrm{C}$ with the vacuum on the order of $10^{-9}$ mbar during the experiment. After the measurement, the samples are usually warmed up in the vacuum and reexamined at room temperature. The technique allows to study mineral/solution interfaces with the water (ice) layer thickness of about $1 \mathrm{~nm}$ and electrolyte concentrations below $0.05-0.1 \mathrm{~mol} / \mathrm{L}$ [183]. The laboratory-based cryo-XPS has been successfully employed for exploration, among many others, of ion adsorption and electrical double layer structures [182,184], sulfur oxidation products of the reaction of goethite and lepidocrocite with aqueous sulfide [185], surfaces of chalcopyrite upon chemical and bacterial leaching [68,186], xanthate-derived collectors adsorbed on the main sulfide minerals [102,103], and other interfaces (see Figures 1 and 2 as examples). Interestingly, some signatures of surface nanobubbles, whose role in flotation is discussed at present $[101,186-190]$, were observed as highly inhomogeneous electrostatic charging of sulfide mineral particles reacted with butyl xanthates $[102,103]$ probably due to widespread cavities and rare ice islets on the hydrophobic surfaces.

The cryo-XPS of fast-frozen pastes is a promising method for quasi in situ studies in mineral processing, especially as that can be easy implemented in commercial laboratory instruments. Some questions regarding this technique still need to be answered. Particularly, it is not quite clear yet how thick the adjacent ice films are at specific materials [183], or how very fine particles (slimes) occurring in mineral slurries [191] upon freezing and collecting the spectra will manifest themselves.

\subsection{Sampling and Exploring Natural Mineral Dispersions}

The majority of XPS studies have been conducted with single minerals or their simple mixtures, whereas real ores, industrial products, and their pulps are very complex in terms of chemical and phase composition, with low concentrations of valuable sulfides and abundant gangue minerals, wide particle size distribution, and presence of solutes and colloids. These entities can interact with sulfide mineral surfaces modifying their characteristics and behavior, and could essentially complicate XPS studies by screening the surface of interest and causing inhomogeneous electrostatic charging. Smart [17] has published a sampling procedure aimed at prevention of ex situ oxidation of the mineral surfaces and rejection of pulp solutes and slimes. Slurry specimens were purged with nitrogen, followed by their sealing and freezing to arrest possible reactions until examination. After thawing, the sample was deslimed through several steps of sonication/decantation, and the aqueous solution was removed after filtering. Then the thickened slurry was loaded into the spectrometer and remaining water was evaporated without contact with air during the pumping. This, or a slightly modified protocol, has been utilized in numerous studies on sulfide minerals and ores, and their interaction with flotation reagents. It can be combined with freeze-drying or fast-freezing techniques [171] to retain volatile species.

Meanwhile, ultrasonic treatment and discarding the slimes may result in the loss of important information about real mineral surfaces in their dispersions. In particular, it was demonstrated that smaller sulfide mineral particles are more oxidized and attract more ferric hydroxides after the comminution in steel mills than coarser ones [192]. The grinding of sulfide ores was found to produce ultrafines in quantities comparable with, or exceeding the amounts of flotation reagents [193,194], particularly serpentine gangues [194-196] which bear positive charge and adhere to negatively-charged sulfide minerals, suppressing their flotation. Thus, correct procedures of sampling and handling of mineral dispersions for XPS exploration still need to be elaborated.

The heterogeneous electrostatic charging can emerge as a serious problem when studying multiphase particulate dispersions with abundant dielectric phases. Usually, an electron flood gun is utilized to eliminate the sample charging [197], but this could be insufficient when bright synchrotron radiation is applied in HAXPES or high lateral resolution XPS and SPEM. Strong charging effects were 
also observed for lab-based cryo-XPS of moderately hydrophobic particles of single minerals [102,103]. Therefore, more sophisticated methods such as a high-energy electron gun [198], low-energy ion beam or gas ionization in AP-XPS [172-175] would be necessary.

Table 1 briefly summarizes the pros and cons of the photoelectron spectroscopy techniques and examples of their utilization in studies on specific sulfide minerals.

Table 1. Principal possibilities and shortcomings of X-ray photoelectron spectroscopy techniques, and examples of the application to sulfide minerals.

\begin{tabular}{|c|c|c|c|}
\hline Technique & $\begin{array}{l}\text { Possibilities and } \\
\text { Findings }\end{array}$ & Drawbacks & Mineral Samples \\
\hline Conventional XPS & $\begin{array}{l}\text { Analysis of surface } \\
\text { reaction products and } \\
\text { adsorbates, } \\
\text { non-stoichiometry }\end{array}$ & $\begin{array}{c}\text { Loss of volatile species; } \\
\text { decay of solid/water } \\
\text { interface }\end{array}$ & numerous minerals, ores \\
\hline Freeze-drying & $\begin{array}{l}\text { Detection of volatile } \\
\text { species } \\
\text { (S, dixanthogens, etc.) }\end{array}$ & $\begin{array}{l}\text { Decay of solid/water } \\
\text { interface }\end{array}$ & $\mathrm{PbS}[44,56] \mathrm{FeS}_{2}[99,100]$ \\
\hline Fast-freezing & $\begin{array}{l}\text { Characterization of volatile } \\
\text { species and solid/water } \\
\text { interfaces }\end{array}$ & $\begin{array}{l}\text { Uncertainty about the } \\
\text { effect of freezing }\end{array}$ & $\begin{array}{c}\mathrm{CuFeS}_{2}[68,102,186] \\
\mathrm{FeS}_{2}, \mathrm{PbS}[102] \\
\mathrm{ZnS}[103]\end{array}$ \\
\hline $\begin{array}{c}\text { Soft SR-XPS } \\
(\mathrm{h} v=100-1000 \mathrm{eV})\end{array}$ & $\begin{array}{l}\text { Tunable excitation energy } \\
\text { and surface sensitivity; } \\
\text { high spectral sensitivity } \\
\text { and resolution }\end{array}$ & $\begin{array}{c}\text { Need of access to SR } \\
\text { facilities, potential sample } \\
\text { damage and loss of volatile } \\
\text { species, decay of } \\
\text { solid/water interface }\end{array}$ & 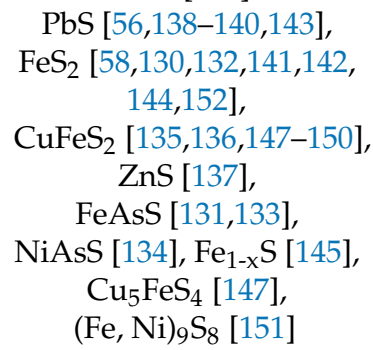 \\
\hline $\begin{array}{c}\text { HAXPES } \\
(\mathrm{h} v=2000-10000 \mathrm{eV})\end{array}$ & $\begin{array}{l}\text { Non-destructive depth } \\
\text { profiling }\end{array}$ & $\begin{array}{l}\text { Mainly buried layers and } \\
\text { interfaces, need of SR } \\
\text { facility access (mostly) }\end{array}$ & $\begin{array}{c}\mathrm{Fe}_{1-\mathrm{xS}}, \mathrm{FeS}_{2}[89] \\
\mathrm{CuFeS}_{2}[90]\end{array}$ \\
\hline SPEM & $\begin{array}{l}\text { Lateral resolution down to } \\
\qquad 100 \mathrm{~nm}\end{array}$ & $\begin{array}{c}\text { Strict requirements to } \\
\text { samples; access to SR } \\
\text { facilities }\end{array}$ & $\begin{array}{c}\mathrm{FeS}_{2}[168] \\
\mathrm{CuFeS}_{2}[169,170]\end{array}$ \\
\hline PEEM & $\begin{array}{l}\text { Lateral resolution down to } \\
\qquad 10 \mathrm{~nm}\end{array}$ & $\begin{array}{l}\text { Limited chemical } \\
\text { information; access to SR } \\
\text { facilities (mostly) }\end{array}$ & $\begin{array}{c}\mathrm{CuFeS}_{2}[165-167], \\
(\mathrm{Ni}, \mathrm{Fe})_{9} \mathrm{~S}_{8}[165], \\
\mathrm{Fe}_{1-\mathrm{x}} \mathrm{S}[165], \mathrm{FeS}_{2}[167]\end{array}$ \\
\hline AP-XPS & $\begin{array}{l}\mathrm{N} \text { situ analysis of solid/gas } \\
\text { and solid/liquid interfaces }\end{array}$ & $\begin{array}{c}\text { Lack of appropriate } \\
\text { techniques; need of SR } \\
\text { facility access (mostly) }\end{array}$ & 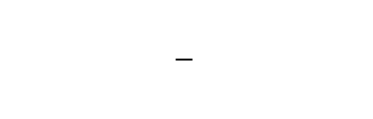 \\
\hline
\end{tabular}

\section{Conclusions and Outlook}

XPS became at present a routine technique for characterization of solid surfaces in mineral processing and related areas. XPS and surface-sensitive SR-XPS successfully specified products formed at mineral surfaces upon their interaction with flotation reagents, including flotation collectors. The method discovered the phenomenon of surface non-stoichiometry caused by the preferential release of metal cations from the sulfide lattices, while depth-resolved high-energy XPS (HAXPES) found that the metal-depleted near-surface is composed of several layers with polysulfides occurring only in the outmost one. It should be stressed that many surface species (elemental sulfur, dixanthogens, polysulfides, etc.) are volatile in the spectrometer vacuum at room temperature so the samples should be cooled before or during their evacuation. The cryogenic XPS of fast-frozen particulate minerals is one of the most promising techniques for (quasi) in situ exploration not only of the unstable surface species, but also adjacent aqueous phase, double electrical layers and adsorbates. This technique is worthy of further development and wider application. The near-ambient pressure XPS, whose application rapidly 
progresses in catalysis and other fields, practically is not in use in mineral processing. Photoelectron microscopy (SPEM and PEEM) methods having high lateral resolution could provide interesting results but are not well suited for common measurements yet. HAXPES, a powerful method for the characterization of thick layers and buried interfaces, is underestimated in the mineral processing studies, especially as commercial laboratory instruments equipped with innovative hard energy X-ray sources are becoming available. The problem of surface studies on real ores is far from being solved; development of spatially resolved methods both in the depth and lateral dimensions together with appropriate sample preparation procedures is still pressing.

Funding: This research was funded by Russian Science Foundation, grant number 18-17-00135.

Conflicts of Interest: The author declares no conflict of interest.

\section{References}

1. Will's Mineral Processing Technology. An Introduction to the Practical Aspects of Ore Treatment and Mineral Recovery, 7th ed.; Wills, B.A., Napier-Munn, T., Eds.; Elsevier Science \& Technology Books: New York, NY, USA, 2006.

2. Bulatovic, S.M. Handbook of Flotation Reagents: Chemistry, Theory and Practice. Volume 1: Flotation of Sulfide Ores, 1st ed.; Elsevier: Boston, MA, USA, 2007. [CrossRef]

3. Free, M.L. Hydrometallurgy: Fundamentals and Applications; John Wiley \& Sons: Hoboken, NJ, USA, 2013.

4. Watling, H.R. Review of biohydrometallurgical metals extraction from polymetallic mineral resources. Minerals 2015, 5, 1-60. [CrossRef]

5. Buckley, A.N.; Hope, G.A.; Woods, R. Metals from sulfide minerals: The role of adsorption of organic reagents in processing technologies. In Solid-Liquid Interfaces, Topics in Applied Physics; Wandelt, K., Thurgate, S., Eds.; Springer: Berlin/Heidelberg, Germany, 2003; Volume 85, pp. 61-96.

6. Liu, G.; Yang, X.; Zhong, H. Molecular design of flotation collectors: A recent progress. Adv. Colloid Interface Sci. 2017, 246, 181-195. [CrossRef]

7. Xing, Y.; Gui, X.; Pan, L.; Pinchasik, B.-E.; Cao, Y.; Liu, J.; Kappl, M.; Butt, H.-J. Recent experimental advances for understanding bubble-particle attachment in flotation. Adv. Colloid Interface Sci. 2017, 246, 105-132. [CrossRef] [PubMed]

8. Krasowska, M.; Malysa, K.; Beattie, D.A. Recent advances in studies of bubble-solid interactions and wetting film stability. Curr. Opin. Colloid Interface Sci. 2019, 44, 48-58. [CrossRef]

9. Chanturiya, V.A.; Kondratiev, S.A. Contemporary understanding and developments in the flotation theory of non-ferrous ores. Miner. Proc. Extr. Metall. Rev. 2019, 40, 390-401. [CrossRef]

10. Buckley, A. Surface science and flotation surface and interface science. In Surface and Interface Science: Applications of Surface Science II, 1st ed.; Wandelt, K., Ed.; Wiley-VCH Verlag GmbH \& Co. KGaA: Weinheim, Germany, 2020; Volume 10, pp. 735-798. [CrossRef]

11. Hackl, R.P.; Dreisinger, D.P.; Peters, E.; King, J.A. Passivation of chalcopyrite during oxidative leaching in sulfate media. Hydrometallurgy 1995, 39, 25-48. [CrossRef]

12. Holmes, P.R.; Crundwell, F.K. Polysulfides do not cause passivation: Results from the dissolution of pyrite and implications for other sulfide minerals. Hydrometallurgy 2013, 139, 101-110. [CrossRef]

13. Li, Y.; Kawashima, N.; Li, J.; Chandra, A.P.; Gerson, A.R. A review of the structure, and fundamental mechanisms and kinetics of the leaching of chalcopyrite. Adv. Colloid Interface Sci. 2013, 197, 1-32. [CrossRef]

14. Zhao, H.; Zhang, Y.; Zhang, X.; Qian, L.; Sun, M.; Yang, Y.; Zhang, Y.; Wang, J.; Kim, H.; Qiu, G. The dissolution and passivation mechanism of chalcopyrite in bioleaching: An overview. Miner. Eng. 2019, 136, 140-154. [CrossRef]

15. Van der Heide, P. X-ray Photoelectron Spectroscopy: An Introduction to Principles and Practices; John Wiley \& Sons, Inc.: Hoboken, NJ, USA, 2012.

16. Vickerman, J.; Gilmore, I. (Eds.) Surface Analysis: The Principal Techniques, 2nd ed.; John Wiley and Sons, Ltd.: Hoboken, NJ, USA, 2009.

17. Smart, R.S.C. Surface layers in base metal sulphide flotation. Miner. Eng. 1991, 4, 891-909. [CrossRef] 
18. Smart, R.S.C.; Amarantidis, J.; Skinner, W.M.; Prestidge, C.A.; La Vanier, L.; Grano, S.R. Surface analytical studies of oxidation and collector adsorption in sulfide mineral flotation. In Solid-Liquid Interfaces. Topics in Applied Physics; Wandelt, K., Thurgate, S., Eds.; Springer: Berlin/Heidelberg, Germany, 2003; Volume 85, pp. 3-62. [CrossRef]

19. Wincott, P.L.; Vaughan, D.J. Spectroscopic studies of sulfides. Rev. Mineral. Geochem. 2006, 61, 181-229. [CrossRef]

20. Rosso, K.M.; Vaughan, D.J. Sulfide mineral surfaces. Rev. Mineral. Geochem. 2006, 61, 505-556. [CrossRef]

21. Rosso, K.M.; Vaughan, D.J. Reactivity of sulfide mineral surfaces. Rev. Mineral. Geochem. 2006, 61, 557-607. [CrossRef]

22. Goh, S.W.; Buckley, A.N.; Gong, B.; Woods, R.; Lamb, R.N.; Fan, L.J.; Yang, Y.W. Thiolate layers on metal sulfides characterised by XPS, ToF-SIMS and NEXAFS spectroscopy. Miner. Eng. 2008, 21, 1026-1037. [CrossRef]

23. Smart, R.S.C.; Gerson, A.R.; Hart, B.R.; Beattie, D.A.; Young, C. Innovations in measurement of mineral structure and surface chemistry in flotation: Past, present, and future. In Mineral Processing and Extractive Metallurgy: 100 Years of Innovation; Society for Mining, Metallurgy \& Exploration Inc.: Englewood, CO, USA, 2014; pp. 577-602.

24. Qian, G.; Li, Y.; Gerson, A.R. Applications of surface analytical techniques in Earth Sciences. Surf. Sci. Rep. 2015, 70, 86-133. [CrossRef]

25. Unger, W.E.S.; Wirth, T.; Hodoroaba, V.-D. Auger electron spectroscopy. In Characterization of Nanoparticles: Measurement Processes for Nanoparticles; Hodoroaba, V.-D., Unger, W.E.S., Shard, A.G., Eds.; Elsevier: Amsterdam, The Netherlands, 2020; pp. 373-395. [CrossRef]

26. Reniersa, F; Tewell, C. New improvements in energy and spatial ( $x, y, z)$ resolution in AES and XPS applications. J. Electron. Spectrosc. Rel. Phenom. 2005, 142, 1-25. [CrossRef]

27. Chehreh Chelgani, S.; Hart, B. TOF-SIMS studies of surface chemistry of minerals subjected to flotation separation-A review. Miner. Eng. 2014, 57, 1-11. [CrossRef]

28. Zaera, F. Probing liquid/solid interfaces at the molecular level. In Surface and Interface Science: Liquid and Biological Interfaces, 1st ed.; Wandelt, K., Ed.; Wiley-VCH Verlag GmbH \& Co. KGaA: Weinheim, Germany, 2020; pp. 1-142. [CrossRef]

29. Little, L.H.; Poling, G.W.; Leja, J. Infrared spectra of xanthate compounds: II. Assignment of vibrational frequencies. Can. J. Chem. 1961, 39, 745-754. [CrossRef]

30. Leppinen, J.O. FT-IR and flotation investigation of the adsorption of ethyl xanthate on activated and non-activated sulfide minerals. Int. J. Miner. Process. 1990, 30, 245-263. [CrossRef]

31. Beattie, D.A.; Larsson, M.L.; Holmgren, A.R. In situ total internal reflection Raman spectroscopy of surfactant adsorption at a mineral surface. Vibr. Spectrosc. 2006, 41, 198-204. [CrossRef]

32. McQuillan, A.J. Probing solid-solution interfacial chemistry with ATR-IR spectroscopy of particle films. Adv. Mater. 2001, 13, 1034-1038. [CrossRef]

33. Escudero, C.; Salmeron, M. From solid-vacuum to solid-gas and solid-liquid interfaces: In situ studies of structure and dynamics under relevant conditions. Surf. Sci. 2013, 607, 2-9. [CrossRef]

34. Rickard, D.; Luther, G.W., III. Chemistry of iron sulfides. Chem. Rev. 2007, 107, 514-562. [CrossRef] [PubMed]

35. Rimstidt, J.D.; Vaughan, D.J. Pyrite oxidation: A state of-the-art-assessment of the reaction mechanism. Geochim. Cosmochim. Acta 2003, 67, 873-880. [CrossRef]

36. Murphy, R.; Strongin, D.R. Surface reactivity of pyrite and related sulfides. Surf. Sci. Rep. 2009, 64, 1-45. [CrossRef]

37. Chandra, A.P.; Gerson, A.R. The mechanisms of pyrite oxidation and leaching: A fundamental perspective. Surf. Sci. Rep. 2010, 65, 93-315. [CrossRef]

38. Wang, H. A review on process-related characteristics of pyrrhotite. Miner. Proc. Extr. Metall. Rev. 2008, 29, 1-41. [CrossRef]

39. Hu, Y.; Wu, M.; Liu, R.; Sun, W. A review on the electrochemistry of galena flotation. Miner. Eng. 2020, 150, 106272. [CrossRef]

40. Manocha, A.S.; Park, R.L. Flotation related ESCA studies on PbS surfaces. Appl. Surf. Sci. 1977, 1, $129-141$. [CrossRef]

41. Brion, D. Etude par spectroscopie de photoélectrons de la dégradation superficielle de $\mathrm{FeS}_{2}, \mathrm{CuFeS}_{2}, \mathrm{ZnS}$ et PbS á l'eau. Appl. Surf. Sci. 1980, 5, 133-152. [CrossRef] 
42. Evans, S.; Raftery, E. Electron spectroscopic studies of galena and its oxidation by microwave-generated oxygen species and by air. J. Chem. Soc. Faraday Trans. I 1982, 78, 3545-3560. [CrossRef]

43. Luttrell, G.H.; Yoon, R.-H. Surface studies of the collectorless flotation of chalcopyrite. Colloids Surf. A 1984, 12, 239-254. [CrossRef]

44. Buckley, A.N.; Woods, R. An X-ray photoelectron spectroscopic study of the oxidation of galena. Appl. Surf. Sci. 1984, 17, 401-414. [CrossRef]

45. Buckley, A.N.; Woods, R. An X-ray photoelectron spectroscopic study of the oxidation of chalcopyrite. Austral. J. Chem. 1984, 37, 2403-2413. [CrossRef]

46. Buckley, A.N.; Hamilton, I.C.; Woods, R. Investigation of the surface oxidation of bornite by linear potential sweep voltammetry and X-ray photoelectron spectroscopy. J. Appl. Electrochem. 1984, 14, 63-74. [CrossRef]

47. Buckley, A.N.; Woods, R. X-ray photoelectron spectroscopy of oxidised pyrrhotite surfaces. II: Exposure to aqueous solutions. Appl. Surf. Sci. 1985, 20, 472-480. [CrossRef]

48. Buckley, A.N.; Woods, R. X-ray photoelectron spectroscopy of oxidized pyrrhotite surfaces: I. Exposure to aire. Appl. Surf. Sci. 1985, 22, 280-287. [CrossRef]

49. Buckley, A.N.; Woods, R. The surface oxidation of pyrite. Appl. Surf. Sci. 1987, 27, 437-452. [CrossRef]

50. Buckley, A.N.; Woods, R.; Wouterlood, H.J. An XPS investigation of the surface of natural sphalerites under flotation-related conditions. Int. J. Miner. Process. 1989, 26, 29-49. [CrossRef]

51. Buckley, A.N.; Wouterlood, H.J.; Woods, R. The surface composition of natural sphalerites under oxidative leaching conditions. Hydrometallurgy 1989, 22, 39-56. [CrossRef]

52. Buckley, A.N.; Woods, R. Electrochemical and XPS studies of the surface oxidation of synthetic heazlewoodite $\left(\mathrm{Ni}_{3} \mathrm{~S}_{2}\right)$. J. Appl. Electrochem. 1991, 21,575-582. [CrossRef]

53. Buckley, A.N.; Woods, R. Surface composition of pentlandite under flotation-related conditions. Surf. Interface Anal. 1991, 17, 675-680. [CrossRef]

54. Buckley, A.N.; Woods, R. Relaxation of the lead-deficient sulfide surface layer on oxidized galena. J. Appl. Electrochem. 1996, 26, 899-907. [CrossRef]

55. Buckley, A.N.; Walker, G.W. The surface composition of arsenopyrite exposed to oxidizing environments. Appl. Surf. Sci. 1988, 35, 227-240. [CrossRef]

56. Laajalehto, K.; Kartio, I.; Heinonen, M.; Laiho, T. Temperature controled photoelectron spectroscopic investigation of volatile species on PbS(100) surface. Jpn. J. Appl. Phys. 1999, 38, 265-268. [CrossRef]

57. Mycroft, J.R.; Bancroft, G.M.; McIntyre, N.S.; Lorimer, J.W.; Hill, I.R. Detection of sulphur and polysulphides on electrochemically oxidized pyrite surfaces by X-ray photoelectron spectroscopy and Raman spectroscopy. J. Electroanal. Chem. Interface Electrochem. 1990, 292, 139-152. [CrossRef]

58. Karthe, S.; Szargan, R.; Suoninen, E. Oxidation of pyrite surfaces: A photoelectron spectroscopic study. Appl. Surf. Sci. 1993, 72, 157-170. [CrossRef]

59. Richardson, P.E.; O’Dell, C.S. Semiconducting characteristics of galena electrodes. Relationship to mineral flotation. J. Electrochem. Soc. 1985, 132, 1350-1356. [CrossRef]

60. Richardson, P.E.; Yoon, R.H.; Woods, R.; Buckley, A.N. The photoelectrochemistry of galena. Int. J. Miner. Process. 1994, 41,77-97. [CrossRef]

61. Mikhlin, Y.; Romanchenko, A.; Shagaev, A. Scanning probe microscopy studies of PbS surfaces oxidized in air and etched in aqueous acid solutions. Appl. Surf. Sci. 2006, 252, 5645-5658. [CrossRef]

62. Buckley, A.N.; Hamilton, I.C.; Woods, R. An investigation of the sulphur (- II)/sulphur (0) system on gold electrodes. J. Electroanal. Chem. Interfacial Electrochem. 1987, 216, 213-227. [CrossRef]

63. Walker, G.W.; Richardson, P.E.; Buckley, A.N. Workshop on the flotation-related surface chemistry of sulfide minerals. Int. J. Miner. Process. 1989, 25, 153-158. [CrossRef]

64. Termes, S.C.; Buckley, A.N.; Gillard, R.D. 2p electron binding energies for the sulfur atoms in metal polysulfides. Inorg. Chim. Acta 1987, 126, 79-82. [CrossRef]

65. Smart, R.S.C.; Skinner, W.M.; Gerson, A.R. XPS of sulphide mineral surfaces: Metal-deficient, polysulphides, defects and elemental sulphur. Surf. Interface Anal. 1999, 28, 101-105. [CrossRef]

66. Gerson, A.R.; Bredow, T. Interpretation of sulphur 2p XPS spectra in sulfide minerals by means of ab initio calculations. Surf. Interface Anal. 2000, 29, 145-150. [CrossRef]

67. Fantauzzi, M.; Elsener, B.; Atzei, D.; Rigoldi, A.; Rossi, A. Exploiting XPS for the identification of sulfides and polysulfides. RSC Adv. 2015, 5, 75953-75963. [CrossRef] 
68. Nasluzov, V.; Shor, A.; Romanchenko, A.; Tomashevich, Y.; Mikhlin, Y. DFT+U and low-temperature XPS studies of Fe-depleted chalcopyrite $\left(\mathrm{CuFeS}_{2}\right)$ surfaces: A focus on polysulfide species. J. Phys. Chem. C 2019, 123, 21031-21041. [CrossRef]

69. Parker, G.K.; Woods, R.; Hope, G.A. Raman investigation of chalcopyrite oxidation. Colloids Surf. A Physicochem. Eng. Asp. 2008, 318, 160-168. [CrossRef]

70. Parker, G.K.; Hope, G.A.; Woods, R. Gold-enhanced Raman observation of chalcopyrite leaching. Colloids Surf. A Physicochem. Eng. Asp. 2008, 325, 132-140. [CrossRef]

71. Smart, R.S.C.; Jasieniak, M.; Prince, K.E.; Skinner, W.M. SIMS studies of oxidation mechanisms and polysulfide formation in reacted sulfide surfaces. Miner. Eng. 2000, 13, 857-870. [CrossRef]

72. Klauber, C.; Parker, A.; Van Bronswijk, W.; Watling, H.R. Sulphur speciation of leached chalcopyrite surfaces as determined by X-ray photoelectron spectroscopy. Int. J. Miner. Process. 2001, 62, 65-94. [CrossRef]

73. Parker, A.; Klauber, C.; Kougianos, A.; Watling, H.R.; Van Bronswijk, W. An X-ray photoelectron spectroscopy study of the mechanism of oxidative dissolution of chalcopyrite. Hydrometallurgy 2003, 71, 265-276. [CrossRef]

74. Klauber, C. A critical review of the surface chemistry of acidic ferric sulphate dissolution of chalcopyrite with regards to hindered dissolution. Int. J. Miner. Process. 2008, 86, 1-17. [CrossRef]

75. Jones, C.F.; LeCount, S.; Smart, R.; White, T.J. Compositional and structural alteration of pyrrhotite surfaces in solution: XPS and XRD studies. Appl. Surf. Sci. 1992, 55, 65-85. [CrossRef]

76. Pratt, A.R.; Muir, I.J.; Nesbitt, H.W. X-ray photoelectron and auger electron spectroscopic studies of pyrrhotite, and mechanism of air oxidation. Geochim. Cosmochim. Acta 1994, 58, 827-841. [CrossRef]

77. Pratt, A.R.; Nesbitt, H.W.; Muir, I.J. Generation of acids from mine waste: Oxidative leaching of pyrrhotite in dilute $\mathrm{H}_{2} \mathrm{SO}_{4}$ solutions (pH 3). Geochim. Cosmochim. Acta 1994, 58, 5147-5159. [CrossRef]

78. Mycroft, J.R.; Nesbitt, H.W.; Pratt, A.R. X-ray photoelectron and auger electron spectroscopy of air-oxidized pyrrhotite: Distribution of oxidized species with depth. Geochim. Cosmochim. Acta 1995, 59, 721-733. [CrossRef]

79. Pratt, A.R.; Nesbitt, H.W. Pyrrhotite leaching in acid mixtures of $\mathrm{HCl}$ and $\mathrm{H}_{2} \mathrm{SO}_{4}$. Am. J. Sci. 1997, 297, 807-820. [CrossRef]

80. Mikhlin, Y.L.; Tomashevich, Y.V.; Pashkov, G.L.; Okotrub, A.V.; Asanov, I.P.; Mazalov, L.N. Electronic structure of non-equilibrium iron-deficient layer at hexagonal pyrrhotite. Appl. Surf. Sci. 1998, 125, 73-84. [CrossRef]

81. Mikhlin, Y.; Varnek, V.; Asanov, I.; Tomashevich, Y.; Okotrub, A.; Livshits, A.; Selyutin, G.; Pashkov, G. Reactivity of pyrrhotite $\left(\mathrm{Fe}_{9} \mathrm{~S}_{10}\right)$ surfaces: Spectroscopic studies. Phys. Chem. Chem. Phys. 2000, 2, 4393-4398. [CrossRef]

82. Mikhlin, Y. Reactivity of pyrrhotite surfaces: An electrochemical study. Phys. Chem. Chem. Phys. 2000, 2, 5672-5677. [CrossRef]

83. Mikhlin, Y.L.; Kuklinskiy, A.V.; Pavlenko, N.I.; Varnek, V.A.; Asanov, I.P.; Okotrub, A.V.; Selyutin, G.E.; Solovyev, L.A. Spectroscopic and XRD studies of the air degradation of acid-reacted pyrrhotites. Geochim. Cosmochim. Acta 2002, 66, 4077-4087. [CrossRef]

84. Thomas, J.E.; Jones, C.F.; Skinner, W.M.; Smart, R.; White, T.J. The role of surface sulphur species in the inhibition of pyrrhotite dissolution in acid conditions. Geochim. Cosmochim. Acta 1998, 62, 1555-1565. [CrossRef]

85. Thomas, J.; Smart, R.; Skinner, W. Kinetic factors for oxidative and non-oxidative dissolution of iron sulfides. Miner. Eng. 2000, 13, 1149-1159. [CrossRef]

86. Thomas, J.E.; Skinner, W.M.; Smart, R.S.C. A mechanism to explain sudden changes in rates and products for pyrrhotite dissolution in acid solution. Geochim. Cosmochim. Acta 2001, 65, 1-12. [CrossRef]

87. Mikhlin, Y.L.; Tomashevich, Y.V.; Asanov, I.P.; Okotrub, A.V.; Varnek, V.A.; Vyalikh, D.V. Spectroscopic and electrochemical characterization of the surface layers of chalcopyrite $\left(\mathrm{CuFeS}_{2}\right)$ reacted in acidic solutions. Appl. Surf. Sci. 2004, 225, 395-409. [CrossRef]

88. Harmer, S.L.; Thomas, J.E.; Fornasiero, D.; Gerson, A.R. The evolution of surface layers formed during chalcopyrite leaching. Geochim. Cosmochim. Acta 2006, 70, 4392-4402. [CrossRef]

89. Mikhlin, Y.; Tomashevich, Y.; Vorobyev, S.; Saikova, S.; Romanchenko, A.; Félix, R. Hard X-ray photoelectron and X-ray absorption spectroscopy characterization of oxidized surfaces of iron sulfides. Appl. Surf. Sci. 2016, 387, 796-804. [CrossRef] 
90. Mikhlin, Y.; Nasluzov, V.; Romanchenko, A.; Tomashevich, Y.; Shor, A.; Félix, R. Layered structure of the near-surface region of oxidized chalcopyrite $\left(\mathrm{CuFeS}_{2}\right)$ : Hard X-ray photoelectron spectroscopy, $\mathrm{X}$-ray absorption spectroscopy and DFT+U studies. Phys. Chem. Chem. Phys. 2017, 19, 2749-2759. [CrossRef]

91. Nowak, P.; Laajalehto, K.; Kartio, I. A flotation related X-ray photoelectron spectroscopy study of the oxidation of galena surface. Colloids Surf. A Physicochem. Eng. Asp. 2000, 161, 447-460. [CrossRef]

92. Buckley, A.N.; Goh, S.W.; Lamb, R.N.; Woods, R. Interaction of thiol collectors with pre-oxidised sulfide minerals. Int. J. Miner. Process. 2003, 72, 163-174. [CrossRef]

93. Niu, X.; Chen, J.; Li, Y.; Xia, L.; Li, L.; Sun, H.; Ruan, R. Correlation of surface oxidation with xanthate adsorption and pyrite flotation. Appl. Surf. Sci. 2019, 495, 143411. [CrossRef]

94. Moimane, T.; Plackowski, C.; Peng, Y. The critical degree of mineral surface oxidation in copper sulphide flotation. Miner. Eng. 2020, 145, 106075. [CrossRef]

95. Shchukarev, A.V.; Kravets, I.M.; Buckley, A.N.; Woods, R. Submonolayer adsorption of alkyl xanthates on galena. Int. J. Miner. Process. 1994, 41, 99-114. [CrossRef]

96. Mielczarski, J.A.; Mielczarski, E.; Cases, J.M. Influence of chain length on adsorption of xanthates on chalcopyrite. Int. J. Miner. Process. 1998, 52, 215-231. [CrossRef]

97. Piantadosi, C.; Smart, R.S.C. Statistical comparison of hydrophobic and hydrophilic species on galena and pyrite particles in flotation concentrates and tails from TOF-SIMS evidence. Int. J. Miner. Process. 2002, 64, 43-54. [CrossRef]

98. Kartio, I.; Laajalehto, K.; Suoninen, E.; Karthe, S.; Szargan, R. Technique for XPS measurements of volatile adsorbed layers: Application to studies of sulphide flotation. Surf. Interface Anal. 1992, 18, 807-810. [CrossRef]

99. Szargan, R.; Karthe, S.; Suoninen, E. XPS studies of xanthate adsorption on pyrite. Appl. Surf. Sci. 1992, 55, 227-232. [CrossRef]

100. Deng, M.J.; Karpuzov, D.; Liu, Q.X.; Xu, Z.H. Cryo-XPS study of xanthate adsorption on pyrite. Suf. Interface Anal. 2013, 45, 805-810. [CrossRef]

101. Mikhlin, Y.L.; Karacharov, A.A.; Likhatski, M.N. Effect of adsorption of butyl xanthate on galena, PbS, and HOPG surfaces as studied by atomic force microscopy and spectroscopy and XPS. Int. J. Miner. Process. 2015, 144, 81-89. [CrossRef]

102. Mikhlin, Y.; Karacharov, A.; Tomashevich, Y.; Shchukarev, A. Cryogenic XPS study of fast-frozen sulfide minerals: Flotation-related adsorption of n-butyl xanthate and beyond. J. Electron Spectrosc. Rel. Phenom. 2016, 206, 65-73. [CrossRef]

103. Mikhlin, Y.; Karacharov, A.; Tomashevich, Y.; Shchukarev, A. Interaction of sphalerite with potassium n-butyl xanthate and copper sulfate solutions studied by XPS of fast-frozen samples and zeta-potential measurement. Vacuum 2016, 125, 98-105. [CrossRef]

104. Mikhlin, Y.; Vorobyev, S.; Saikova, S.; Tomashevich, Y.; Fetisova, O.; Kozlova, S.; Zharkov, S. Preparation and characterization of colloidal copper xanthate nanoparticles. New J. Chem. 2016, 40, 3059-3065. [CrossRef]

105. Vorobyev, S.; Saikova, S.; Novikova, S.; Fetisova, O.; Zharkov, S.; Krylov, A.; Likhatski, M.; Mikhlin, Y. Colloidal and immobilized nanoparticles of lead xanthates. ACS Omega 2019, 4, 11472-11480. [CrossRef]

106. Firkala, T.; Kuschewski, F.; Nörenberg, T.; Klopf, J.M.; Pashkin, A.; Foerstendorf, H.; Rudolph, M.; Kehr, S.C.; Eng, L.M. Near-field optical examination of potassium n-butyl xanthate/chalcopyrite flotation products. Minerals 2018, 8, 118. [CrossRef]

107. Nefedov, V.I.; Salyn, Y.V.; Solozhenkin, P.M.; Pulatov, G.Y. X-ray photoelectron study of surface compounds formed during flotation of minerals. Surf. Interface Anal. 1980, 2, 170-172. [CrossRef]

108. Prestidge, C.A.; Skinner, W.M.; Ralston, J.; Smart, R.S.C. Copper II activation and cyanide deactivation of zinc sulphide under mildly alkaline conditions. Appl. Surf. Sci. 1997, 108, 333-344. [CrossRef]

109. Finkelstein, N.P. The activation of sulphide minerals for flotation: A review. Int. J. Miner. Process. 1997, 52, 81-120. [CrossRef]

110. Kartio, I.J.; Basilio, C.I.; Yoon, R.H. An XPS study of sphalerite activation by copper. Langmuir 1998, 14, 5274-5278. [CrossRef]

111. Gerson, A.R.; Lange, A.G.; Prince, K.E.; Smart, R.S.C. The mechanism of copper activation of sphalerite. Appl. Surf. Sci. 1999, 137, 207-223. [CrossRef] 
112. Pattrick, R.A.D.; England, K.E.R.; Charnock, J.M.; Mosselmans, J.F.W. Copper activation of sphalerite and its reaction with xanthate in relation to flotation: An X-ray absorption spectroscopy (reflection extended X-ray absorption fine structure) investigation. Int. J. Miner. Process. 1999, 55, 247-265. [CrossRef]

113. Weisener, C.; Gerson, A. An investigation of the $\mathrm{Cu}$ (II) adsorption mechanism on pyrite by ARXPS and SIMS. Miner. Eng. 2000, 13, 1329-1340. [CrossRef]

114. Harmer, S.L.; Mierczynska-Vasilev, A.; Beattie, D.A.; Shapter, J.G. The effect of bulk iron concentration and heterogeneities on the copper activation of sphalerite. Miner. Eng. 2008, 21, 1005-1012. [CrossRef]

115. Simpson, D.J.; Bredow, T.; Chandra, A.P.; Cavallaro, G.P.; Gerson, A.R. The effect of iron and copper impurities on the wettability of sphalerite (110) surface. J. Comput. Chem. 2011, 32, 2022-2030. [CrossRef] [PubMed]

116. Chandra, A.P.; Gerson, A.R. A review of the fundamental studies of the copper activation mechanisms for selective flotation of the sulfide minerals, sphalerite and pyrite. Adv. Colloid Interface Sci. 2009, 145, 97-110. [CrossRef] [PubMed]

117. Chandra, A.P.; Puskar, L.; Simpson, D.J.; Gerson, A.R. Copper and xanthate adsorption onto pyrite surfaces: Implications for mineral separation through flotation. Int. J. Miner. Process. 2012, 114, 16-26. [CrossRef]

118. Wang, J.; Liu, Q.; Zeng, H. Understanding copper activation and xanthate adsorption on sphalerite by ToF-SIMS, XPS and in-situ SECM. J. Phys. Chem. C 2013, 117, 20089-20097. [CrossRef]

119. Ejtemaei, M.; Nguyen, A.V. A comparative study of the attachment of air bubbles onto sphalerite and pyrite surfaces activated by copper sulphate. Miner. Eng. 2017, 109, 14-20. [CrossRef]

120. Wittstock, G.; Kartio, I.; Hirsch, D.; Kunze, S.; Szargan, R. Oxidation of galena in acetate buffer investigated by atomic force microscopy and photoelectron spectroscopy. Langmuir 1996, 12, 5709-5721. [CrossRef]

121. Kartio, I.; Wittstock, G.; Laajalehto, K.; Hirsch, D.; Simola, J.; Laiho, T.; Szargan, R.; Suoninen, E. Detection of elemental sulphur on galena oxidized in acidic solution. Int. J. Miner. Process. 1997, 51, 293-301. [CrossRef]

122. De Giudici, G.; Ricci, P.; Lattanzi, P.; Anedda, A. Dissolution of the (001) surface of galena: An in situ assessment of surface speciation by fluid-cell micro-Raman spectroscopy. Am. Mineral. 2007, 92, 518-524. [CrossRef]

123. Hampton, M.A.; Plackowski, C.; Nguyen, A.V. Physical and chemical analysis of elemental sulfur formation during galena surface oxidation. Langmuir 2011, 27, 4190-4201. [CrossRef] [PubMed]

124. Palyanova, G.A.; Mikhlin, Y.L.; Karmanov, N.S.; Kokh, K.A.; Seryotkin, Y.V. Visible and "invisible" forms of gold and silver in the crystallization products of melts in the Fe-S-Ag-Au system: Experimental data. Doklady Earth Sci. 2017, 474, 636-640. [CrossRef]

125. Goh, S.W.; Buckley, A.N.; Lamb, R.N.; Woods, R. The ability of static secondary ion mass spectrometry to discriminate submonolayer from multilayer adsorption of thiol collectors. Miner. Eng. 2006, 19, 571-581. [CrossRef]

126. Ruano, G.; Pomiro, F.; Ferrón, J. Surface chemical reactions induced on pyrite by ion bombardment. Surf. Sci. 2018, 667, 138-147. [CrossRef]

127. Galvez-Martinez, S.; Escamilla-Roa, E.; Zorzano, M.-P.; Mateo-Marti, E. Ar ${ }^{+}$ion bombardment dictates glycine adsorption on pyrite (100) surface: X-ray photoemission spectroscopy and DFT approach. Appl. Surf. Sci. 2020, 530, 147182. [CrossRef]

128. Woicik, J.C. (Ed.) Hard X-ray Photoelectron Spectroscopy (HAXPES); Springer: Cham, Switzerland, 2016.

129. Brown, G.E., Jr.; Sturchio, N.C. An overview of synchrotron radiation applications to low temperature geochemistry and environmental science. Rev. Mineral. Geochem. 2002, 49, 1-115. [CrossRef]

130. Nesbitt, H.W.; Muir, I.J. X-ray photoelectron spectroscopic study of a pristine pyrite surface reacted with water vapour and air. Geochim. Cosmochim. Acta 1994, 58, 4667-4679. [CrossRef]

131. Nesbitt, H.W.; Muir, I.J.; Pratt, A.R. Oxidation of arsenopyrite by air and air-saturated, distilled water, and implications for mechanism of oxidation. Geochim. Cosmochim. Acta 1995, 59, 1773-1786. [CrossRef]

132. Nesbitt, H.W.; Bancroft, G.M.; Pratt, A.R.; Scaini, M.J. Sulfur and iron surface states on fractured pyrite surfaces. Am. Mineral. 1998, 83, 1067-1076. [CrossRef]

133. Schaufuss, A.G.; Nesbitt, H.W.; Scaini, M.J.; Hoechst, H.; Bancroft, M.G.; Szargan, R. Reactivity of surface sites on fractured arsenopyrite (FeAsS) toward oxygen. Am. Miner. 2000, 85, 1754-1766. [CrossRef]

134. Nesbitt, H.W.; Schaufuss, A.; Sciani, M.; Hochst, H.; Bancroft, G.M.; Szargan, R. Monitoring fundamental reactions at $\mathrm{NiAsS}$ surfaces by synchrotron radiation $\mathrm{X}$-ray photoelectron spectroscopy: As and $\mathrm{S}$ air oxidation by consecutive reaction schemes. Geochim. Cosmochim. Acta 2003, 67, 845-858. [CrossRef] 
135. Harmer, S.L.; Pratt, A.R.; Nesbitt, W.H.; Fleet, M.E. Sulfur species at chalcopyrite $\left(\mathrm{CuFeS}_{2}\right)$ fracture surfaces. Am. Mineral. 2004, 89, 1026-1032. [CrossRef]

136. Von Oertzen, G.U.; Harmer, S.L.; Skinner, W.M. XPS and ab initio calculation of surface states of sulfide minerals: Pyrite, chalcopyrite and molybdenite. Mol. Simul. 2006, 32, 1207-1212. [CrossRef]

137. Harmer, S.L.; Nesbitt, H.W.; Skinner, W.M.; Buckley, A.N.; Pratt, A. ARXPS and SXPS evidence for surface stabilization of sphalerite $\mathrm{Zn}_{1-\mathrm{x}} \mathrm{Fe}_{\mathrm{x}} \mathrm{S}$ (110) surfaces. ECS Trans. 2010, 28, 81-90. [CrossRef]

138. Kartio, I.; Laajalehto, K.; Suoninen, E. Application of electron spectroscopy to characterization of mineral surfaces in flotation studies. Colloids Surf. A Physicochem. Eng. Asp. 1994, 93, 149-158. [CrossRef]

139. Laajalehto, K.; Kartio, I.; Suoninen, E. XPS and SR-XPS techniques applied to sulphide mineral surfaces. Int. J. Miner. Process. 1997, 51, 163-170. [CrossRef]

140. Kartio, I.; Laajalehto, K.; Kaurila, T.; Suoninen, E. A study of galena (PbS) surfaces under controlled potential in $\mathrm{pH} 4.6$ solution by synchrotron radiation excited photoelectron spectroscopy. Appl. Surf. Sci. 1996, 93, 167-177. [CrossRef]

141. Schaufuß, A.G.; Nesbitt, H.W.; Kartio, I.; Laajalehto, K.; Bancroft, G.M.; Szargan, R. Incipient oxidation of fractured pyrite surfaces in air. J. Electron Spectrosc. Rel. Phenom. 1998, 96, 69-82. [CrossRef]

142. Schaufuß, A.G.; Nesbitt, H.W.; Kartio, I.; Laajalehto, K.; Bancroft, G.M.; Szargan, R. Reactivity of surface chemical states on fractured pyrite. Surf. Sci. 1998, 411, 321-328. [CrossRef]

143. Kartio, I.; Laajalehto, K.; Suoninen, E. Characterization of the ethyl xanthate adsorption layer on galena (PbS) by synchrotron radiation excited photoelectron spectroscopy. Colloids Surf. A Physicochem. Eng. Asp. 1999, 154, 97-101. [CrossRef]

144. Nesbitt, H.W.; Scaini, M.; Hochst, H.; Bancroft, G.M.; Schaufuss, A.G.; Szargan, R. Synchrotron XPS evidence for $\mathrm{Fe}^{2+}-\mathrm{S}$ and $\mathrm{Fe}^{3+}-\mathrm{S}$ surface species on pyrite fracture-surfaces, and their 3D electronic states. Am. Mineral. 2000, 85, 850-857. [CrossRef]

145. Nesbitt, H.W.; Schaufuss, A.G.; Scaini, M.; Bancroft, G.M.; Szargan, R. XPS measurement of fivefold and sixfold coordinated sulfur in pyrrhotites and evidence for millerite and pyrrhotite surface species. Am. Mineral. 2001, 86, 318-326. [CrossRef]

146. Goh, S.W.; Buckley, A.N.; Skinner, W.M.; Fan, L.J. An X-ray photoelectron and absorption spectroscopic investigation of the electronic structure of cubanite, $\mathrm{CuFe}_{2} \mathrm{~S}_{3}$. Phys. Chem. Miner. 2010, 37, 389-405. [CrossRef]

147. Acres, R.G.; Harmer, S.L.; Beattie, D.A. Synchrotron XPS studies of solution exposed chalcopyrite, bornite, and heterogeneous chalcopyrite with bornite. Int. J. Miner. Process. 2010, 94, 43-51. [CrossRef]

148. Acres, R.G.; Harmer, S.L.; Beattie, D.A. Synchrotron XPS, NEXAFS, and ToF-SIMS studies of solution exposed chalcopyrite and heterogeneous chalcopyrite with pyrite. Miner. Eng. 2010, 23, 928-936. [CrossRef]

149. Yang, Y.; Harmer, S.; Chen, M. Synchrotron X-ray photoelectron spectroscopic study of the chalcopyrite leached by moderate thermophiles and mesophiles. Miner. Eng. 2014, 69, 185-195. [CrossRef]

150. Yang, Y.; Harmer, S.; Chen, M. Synchrotron-based XPS and NEXAFS study of surface chemical species during electrochemical oxidation of chalcopyrite. Hydrometallurgy 2015, 156, 89-98. [CrossRef]

151. Pettifer, Z.E.; Quinton, J.S.; Skinner, W.M.; Harmer, S.L. New interpretation and approach to curve fitting synchrotron X-ray photoelectron spectra of $(\mathrm{Fe}, \mathrm{Ni})_{9} \mathrm{~S}_{8}$ fracture surfaces. Appl. Surf. Sci. 2020, 504, 144458. [CrossRef]

152. Von Oertzen, G.U.; Skinner, W.M.; Nesbitt, H.W.; Pratt, A.R.; Buckley, A.N. Cu adsorption on pyrite (100): $\mathrm{Ab}$ initio and spectroscopic studies. Surf. Sci. 2007, 601, 5794-5799. [CrossRef]

153. Weiland, C.; Rumaiz, A.K.; Pianetta, P.; Woicik, J.C. Recent applications of hard X-ray photoelectron spectroscopy. J. Vac. Sci. Technol. A 2016, 34, 030801. [CrossRef]

154. Regoutz, A.; Mascheck, M.; Wiell, T.; Eriksson, S.K.; Liljenberg, C.; Tetzner, K.; Williamson, B.A.D.; Scanlon, D.O.; Palmgren, P. A novel laboratory-based hard X-ray photoelectron spectroscopy system. Rev. Sci. Instrum. 2018, 89, 073105. [CrossRef] [PubMed]

155. Siol, S.; Mann, J.; Newman, J.; Miyayama, T.; Watanabe, K.; Schmutz, P.; Cancellieri, C.; Jeurgens, L.P. Concepts for chemical state analysis at constant probing depth by lab-based XPS/HAXPES combining soft and hard X-ray sources. Surf. Interface Anal. 2020. [CrossRef]

156. Nicol, M.; Miki, H.; Velásquez-Yévenes, L. The dissolution of chalcopyrite in chloride solutions: Part 3. Mechanisms. Hydrometallurgy 2010, 103, 86-95. [CrossRef] 
157. Pugaev, D.; Nicol, M.; Senanayake, G. The mechanisms of the passivation of sulfide minerals in oxidative leaching processes. In Proceedings of the 6th Southern African Base Metals Conference, Phalaborwa, South Africa, 18-21 July 2011; pp. 39-48.

158. Li, Y.; Wei, Z.; Qian, G.; Li, J.; Gerson, A.R. Kinetics and mechanisms of chalcopyrite dissolution at controlled redox potential of $750 \mathrm{mV}$ in sulfuric acid solution. Minerals 2016, 6, 83. [CrossRef]

159. Crundwell, F.K. The semiconductor mechanism of dissolution and the pseudopassivation of chalcopyrite. Can. Metall. Q. 2015, 54, 279-288. [CrossRef]

160. O'Connor, G.M.; Eksteen, J.J. A critical review of the passivation and semiconductor mechanisms of chalcopyrite leaching. Miner. Eng. 2020, 154, 106401. [CrossRef]

161. Kiskinova, M. Spectromicroscopy studies with high spatial resolution. Surf. Rev. Lett. 2000, 7, 447-453. [CrossRef]

162. Abyaneh, M.K.; Gregoratti, L.; Amati, M.; Dalmiglio, M.; Kiskinova, M. Scanning photoelectron microscopy: A powerful technique for probing micro and nano-structures. J. Surf. Sci. Nanotechnol. 2011, 9, 158-162. [CrossRef]

163. Mino, L.; Borfecchia, E.; Segura-Ruiz, J.; Giannini, C.; Martinez-Criado, G. Materials characterization by synchrotron X-ray microprobes and nanoprobes. Rev. Modern Phys. 2018, 90, 025007. [CrossRef]

164. Schofield, P.F.; Smith, A.D.; Scholl, A.; Doran, A.; Covey-Crump, S.J.; Young, A.T.; Ohldag, H. Chemical and oxidation-state imaging of mineralogical intergrowths: The application of X-ray photo-emission electron microscopy (XPEEM). Coord. Chem. Rev. 2014, 277-278, 31-43. [CrossRef]

165. Acres, R.G.; Harmer, S.L.; Beattie, D.A. Synchrotron PEEM and ToF-SIMS study of oxidized heterogeneous pentlandite, pyrrhotite and chalcopyrite. J. Synchrotron Rad. 2010, 17, 606-615. [CrossRef] [PubMed]

166. Kalegowda, Y.; Chan, Y.-L.; Wei, D.-H.; Harmer, S.L. X-PEEM, XPS and ToF-SIMS characterisation of xanthate induced chalcopyrite flotation: Effect of pulp potential. Surf. Sci. 2015, 635, 70-77. [CrossRef]

167. Acres, R.G.; Harmer, S.L.; Shui, H.W.; Chen, C.-H.; Beattie, D.A. Synchrotron scanning photoemission microscopy of homogeneous and heterogeneous metal sulfide. J. Synchrotron Rad. 2011, 18, 649-657. [CrossRef]

168. Chandra, A.P.; Gerson, A.R. Pyrite $\left(\mathrm{FeS}_{2}\right)$ oxidation: A sub-micron synchrotron investigation of the initial steps. Geochim. Cosmochim. Acta 2011, 75, 6239-6254. [CrossRef]

169. Li, Y.; Chandra, A.P.; Gerson, A.R. Scanning photoelectron microscopy studies of freshly fractured chalcopyrite exposed to $\mathrm{O}_{2}$ and $\mathrm{H}_{2} \mathrm{O}$. Geochim. Cosmochim. Acta 2014, 133, 372-386. [CrossRef]

170. Li, Y.; Qian, G.; Brown, P.L.; Gerson, A.R. Chalcopyrite dissolution: Scanning photoelectron microscopy examination of the evolution of sulfur species with and without added iron or pyrite. Geochim. Cosmochim. Acta 2017, 212, 33-47. [CrossRef]

171. Shchukarev, A. XPS at solid-aqueous solution interface. Adv. Colloid Interface Sci. 2016, 122, $149-157$. [CrossRef]

172. Salmeron, M.; Schlögl, R. Ambient pressure photoelectron spectroscopy: A new tool for surface science and nanotechnology. Surf. Sci. Rep. 2008, 63, 169-199. [CrossRef]

173. Arble, C.; Jia, M.; Newberg, J.T. Lab-based ambient pressure X-ray photoelectron spectroscopy from past to present. Surf. Sci. Rep. 2018, 73, 37-57. [CrossRef]

174. Head, A.R.; Bluhm, H. Ambient pressure X-ray photoelectron spectroscopy. In Encyclopedia of Interfacial Chemistry; Wandelt, K., Ed.; Elsevier: Amsterdam, The Netherlands, 2018; pp. 13-27. [CrossRef]

175. Patel, D.I.; Roychowdhury, T.; Jain, V.; Shah, D.; Avval, T.G.; Chatterjee, S.; Bahr, S.; Dietrich, P.; Meyer, M.; Thißen, A.; et al. Introduction to near-ambient pressure X-ray photoelectron spectroscopy characterization of various materials. Surf. Sci. Spectra 2019, 26, 016801. [CrossRef]

176. Braun, A. In situ photoelectron spectroscopy. In Encyclopedia of Interfacial Chemistry; Wandelt, K., Ed.; Elsevier: Amsterdam, The Netherlands, 2018; pp. 264-279. [CrossRef]

177. Brown, M.A.; Jordan, I.; Redondo, A.B.; Kleibert, A.; Wörner, H.J.; van Bokhoven, J.A. In situ photoelectron spectroscopy at the liquid/nanoparticle interface. Surf. Sci. 2013, 610,1-6. [CrossRef]

178. Starr, D.E.; Favaro, M.; Abdi, F.F.; Bluhm, H.; Crumlin, E.J.; van de Krol, R. Combined soft and hard X-ray ambient pressure photoelectron spectroscopy studies of semiconductor/electrolyte interfaces. J. Electron Spectrosc. Rel. Phenom. 2017, 221, 106-115. [CrossRef] 
179. Endo, R.; Watanabe, D.; Shimomura, M.; Masuda, T. In situ X-ray photoelectron spectroscopy using a conventional $\mathrm{Al}-\mathrm{K} \alpha$ source and an environmental cell for liquid samples and solid-liquid interfaces. Appl. Phys. Lett. 2019, 114, 173702. [CrossRef]

180. Burger, K.; Fluck, E. X-ray-photoelectron spectroscopy (ESCA) investigations in coordination chemistry, I. Solvation of $\mathrm{SbCl}_{5}$ studied in quick-frozen solutions. Inorg. Nucl. Chem. Lett. 1974, 10, 171-177. [CrossRef]

181. Shchukarev, A.; Sjöberg, S. XPS with fast-frozen samples: A renewed approach to study the real mineral/solution interface. Surf. Sci. 2005, 584, 106-112. [CrossRef]

182. Shchukarev, A. Electrical double layer at the mineral-aqueous solution interface as probed by XPS with fast-frozen samples. J. Electron Spectrosc. Relat. Phenom. 2010, 176, 13-17. [CrossRef]

183. Shchukarev, A.; Ramstedt, M. Cryo-XPS: Probing intact interfaces in nature and life. Surf. Interface Anal. 2017, 49, 349-356. [CrossRef]

184. Kozin, P.A.; Shchukarev, A.; Boily, J.-F. Electrolyte ion binding at iron oxyhydroxide mineral surfaces. Langmuir 2013, 29, 12129-12137. [CrossRef]

185. Wan, M.; Shchukarev, A.; Lohmayer, R.; Planer-Friedrich, B.; Peiffer, S. Occurrence of surface polysulfides during the interaction between ferric (hydr)oxides and aqueous sulfide. Environ. Sci. Technol. 2014, 48, 5076-5084. [CrossRef]

186. Khoshkhoo, M.; Dopson, M.; Shchukarev, A.; Sandström, Å. Chalcopyrite leaching and bioleaching: An X-ray photoelectron spectroscopic (XPS) investigation on the nature of hindered dissolution. Hydrometallurgy 2014, 149, 220-227. [CrossRef]

187. Hampton, M.A.; Nguyen, A.V. Accumulation of dissolved gases at hydrophobic surfaces in water and sodium chloride solutions: Implications for coal flotation. Miner. Eng. 2009, 22, 786-792. [CrossRef]

188. Xing, Y.; Gui, X.; Cao, Y. The hydrophobic force for bubble-particle attachment in flotation-A brief review. Phys. Chem. Chem. Phys. 2017, 19, 24421-24435. [CrossRef] [PubMed]

189. Owens, C.L.; Schach, E.; Rudolph, M.; Nash, G.R. Surface nanobubbles on the carbonate mineral dolomite. RSC Adv. 2018, 8, 35448-35452. [CrossRef]

190. Owens, C.L.; Schach, E.; Heinig, T.; Rudolph, M.; Nash, G.R. Surface nanobubbles on the rare earth fluorcarbonate mineral synchysite. J. Colloid Interface Sci. 2019, 552, 66-71. [CrossRef]

191. Yu, Y.; Ma, L.; Cao, M.; Liu, Q. Slime coatings in froth flotation: A review. Miner. Eng. 2017, 114, $26-36$. [CrossRef]

192. Peng, Y.; Grano, S. Effect of iron contamination from grinding media on the flotation of sulphide minerals of different particle size. Int. J. Miner. Process. 2010, 97, 1-6. [CrossRef]

193. Mikhlin, Y.; Vorobyev, S.; Romanchenko, A.; Karasev, S.; Karacharov, A.; Zharkov, S. Ultrafine particles derived from mineral processing: A case study of the $\mathrm{Pb}-\mathrm{Zn}$ sulfide ore with emphasis on lead-bearing colloids. Chemosphere 2016, 147, 60-66. [CrossRef]

194. Mikhlin, Y.; Romanchenko, A.; Vorobyev, S.; Karasev, S.; Volochaev, M.; Kamenskiy, E.; Burdakova, E. Ultrafine particles in ground sulfide ores: A comparison of four Cu-Ni ores from Siberia, Russia. Ore Geol. Rev. 2017, 81, 1-9. [CrossRef]

195. Bremmell, K.E.; Fornasiero, D.; Ralston, J. Pentlandite-lizardite interactions and implications for their separation by flotation. Colloids Surf. A Physicochem. Eng. Asp. 2005, 252, 207-212. [CrossRef]

196. Liu, D.; Zhang, G.; Chen, Y.; Chen, W.; Gao, Y. A novel method to limit the adverse effect of fine serpentine on the flotation of pyrite. Minerals 2018, 8, 582. [CrossRef]

197. Kelly, M.A. Historical perspectives on charging issues in XPS. J. Electron Spectrosc. Rel. Phenom. 2010, 176, 7-9. [CrossRef]

198. Yasuno, S. Charge compensation in hard X-ray photoelectron spectroscopy by electron beam of several kilo-electron-volts. J. Surf. Anal. 2019, 26, 202-203.

(C) 2020 by the author. Licensee MDPI, Basel, Switzerland. This article is an open access article distributed under the terms and conditions of the Creative Commons Attribution (CC BY) license (http://creativecommons.org/licenses/by/4.0/). 